\title{
Retiolitine graptolites from the Aeronian and lower Telychian (Llandovery, Silurian) of Arctic Canada
}

\author{
Michael J. Melchin, ${ }^{1}$ Alfred C. Lenz, ${ }^{2}$ and Anna Kozłowska ${ }^{3}$ \\ ${ }^{1}$ Department of Earth Sciences, St. Francis Xavier University, Antigonish, Nova Scotia, B2G 2W5, Canada $\langle$ mmelchin@ @stfx.ca \\ ${ }^{2}$ Department of Earth Sciences, Western University Canada, London, Ontario, N6A 5B7, Canada 〈aclenz@uwo.ca〉 \\ ${ }^{3}$ Institute of Paleobiology, Polish Academy of Science, ul. Twarda 51/55, Warsaw, PL-00-818, Poland 〈akd@twarda.pan.pl〉
}

\begin{abstract}
An exceptional fauna of retiolitine graptolites from Aeronian and lowermost Telychian strata in Arctic Canada provides significant new insights into the phylogeny and history of diversity of retiolitine graptolites. All specimens were isolated by dissolution of calcite concretions. The results indicate that retiolitines emerged within the lower Aeronian and reached a higher than expected level of diversity and disparity of forms by mid-Aeronian time. The uppermost Aeronian is almost totally devoid of preserved graptolites in Arctic Canada and, therefore, our material provides few new insights into retiolitine morphology or diversity through that interval. Specimens assigned to Pseudoretiolites? sp. occur in well-dated lower Aeronian strata, thus representing the lowest known biostratigraphic occurrences of retiolitines globally. This taxon appears to be morphologically primitive in that the sicula is completely preserved, with preservation of the proximal regions of theca $1^{1}$, as well as distal thecal fusellum on mature specimens. Cladistic analysis of the Llandovery retiolitines shows that Pseudoretiolites is a stem genus for all of the other retiolitine taxa, which comprise two clades: one consisting of Pseudoplegmatograptus, Retiolites, and Stomatograptus and their derivatives; and the other includes Rotaretiolites, Aeroretiolites, Aeroretiolites?, Eorograptus, Paraplectograptus, Paraplectograptus?, and Sokolovograptus, and all of those other taxa that had previously been placed in the Plectograptinae. We follow the recent proposal that all of the taxa traditionally assigned to the Retiolitidae be assigned to the subfamily Retiolitinae. The following new taxa are described: Pseudoretiolites hyrichus n. sp., Eorograptus spirifer n. sp., and Aeroretiolites cancellatus n. gen. n. sp.
\end{abstract}

\section{Introduction}

It has long been recognized that the earliest known Silurian retiolitine graptolites occur in the mid-Llandovery Aeronian Stage (e.g., Elles and Wood, 1908; Bouček and Münch, 1944; Obut and Sobolevskaya, 1968; Lenz and Melchin, 1987a; Melchin, 1989; Štorch, 1998). Most previous studies that document Aeronian retiolitine faunas, however, report only a single genus, Pseudoretiolites. Exceptions to this include the report of Pseudoplegmatograptus from the upper Aeronian in northwestern Canada (Lenz, 1982), the probable occurrence of that genus in the upper Aeronian in the United Kingdom (Hutt, 1974), as well as the preliminary report of "Rotaretiolites" and "Paraplectograptus" from the Aeronian of Arctic Canada by Lenz and Melchin (1997). This scarcity of information about the patterns of occurrence and morphology of Aeronian retiolitines has led to a significant gap in our understanding of the biostratigraphy and biodiversity history of early retiolitines, in comparison with later Silurian faunas, as well as other Aeronian, non-retiolitine graptolite taxa. This gap has also resulted in difficulties related to our understanding of retiolitine phylogeny. For example, the results of the phylogenetic analysis conducted by Lenz and Melchin (1997), which included "Rotaretiolites" and "Paraplectograptus" in the set of taxa, differed markedly from the phylogeny proposed by Bates et al. (2005), which did not include these hitherto undescribed Aeronian forms and also used a different character coding.

The purposes of this study are to fully document and describe the Aeronian and early Telychian retiolitine graptolite faunas of Arctic Canada (Fig. 1), based on isolated, mainly uncompressed specimens, to document the pattern of diversification of early retiolitine faunas as represented in the Arctic Canadian succession, and to conduct a new phylogenetic analysis of Llandovery retiolitines based on the these new observations. Throughout this paper we follow the family-level classification of Melchin et al. (2011), which assigns all of the taxa traditionally considered to be "retiolitids"-all species with a thecal framework of lists and integrated ancora sleeveto the subfamily Retiolitinae. Therefore, all of these taxa are informally referred to as "retiolitines."

\section{Biostratigraphy}

The Llandovery graptolite biostratigraphy for the Canadian Arctic islands was established by Melchin (1989), who recognized a lower Aeronian Campograptus curtus Zone, subdivided into a lower Demirastrites pectinatus Subzone and upper Rastrites orbitus Subzone, and a mid-Aeronian Lituigraptus convolutus Zone. No graptolites indicative of the upper Aeronian Stimulograptus sedgwickii Zone were found by 


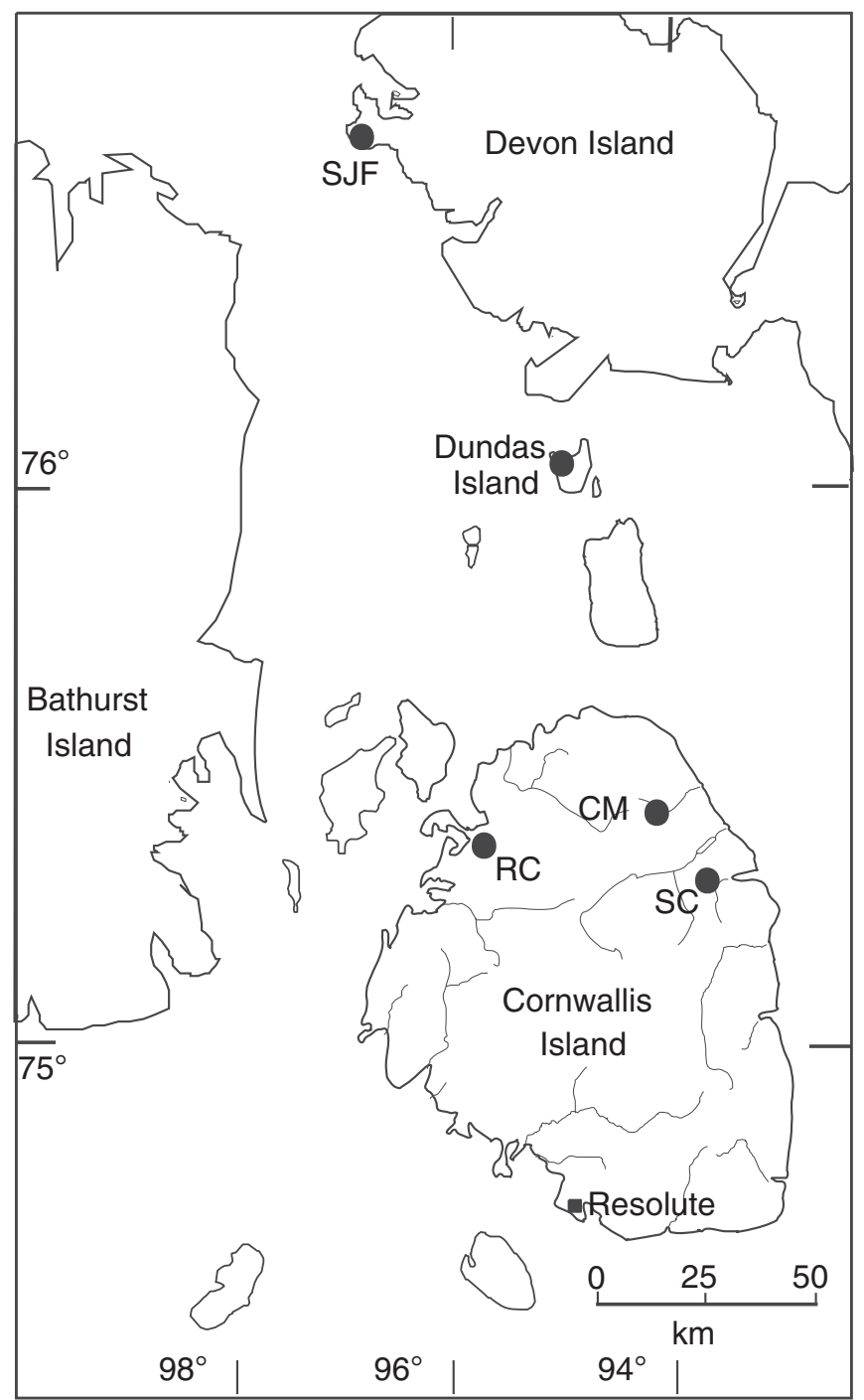

Figure 1. Map of the central Canadian Arctic Islands, showing the collecting localities: $\mathrm{CM}=$ Cape Manning, $\mathrm{SC}=$ Snowblind Creek, $\mathrm{RC}=$ Rookery Creek, $\mathrm{SJF}=$ Cape Sir John Franklin, and Dundas Island.

Melchin (1989), although Melchin and Holmden (2006) noted the discovery of rare graptolites characteristic of this zone at Cape Manning, Cornwallis Island. Recently acquired data (Dawson, 2007; Melchin, 2013) also show that an interval marked by the first appearance of Demirastrites triangulatus occurs below the first occurrence of Demirastrites pectinatus at Cape Manning. As a result, a combined D. triangulatus- $D$. pectinatus Subzone and a $S$. sedgwickii Zone can now be recognized at that section (Figs. 2, 3), which can be readily correlated with the well-known biozonal schemes of Avalonia (Zalasiewicz et al., 2009) and peri-Gondwana (Loydell, 2012). Here we review the previously known biostratigraphic ranges of the each of the retiolitine genera known from the Aeronian and early Telychian and describe the new information provided by these Canadian Arctic faunas. The biostratigraphic occurrences at Cape Manning, the most completely sampled locality in this study, are shown in Figure 3. All other occurrence data are presented in Appendix 1.

\begin{tabular}{|c|c|c|c|c|}
\hline & & $\begin{array}{l}\text { Arctic Canada } \\
\text { (Modified after } \\
\text { Melchin,1989) }\end{array}$ & $\begin{array}{c}\text { Britain } \\
\text { Zalasiewicz } \\
\text { et al., } 2009\end{array}$ & $\begin{array}{c}\text { Peri-Gondwana } \\
\text { Loydell, } 2012\end{array}$ \\
\hline \multirow{9}{*}{ 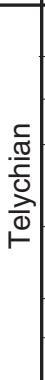 } & \multicolumn{2}{|c|}{ Cy. insectus } & Cy. insectus & Cy. insectus \\
\hline & \multicolumn{2}{|c|}{ Cy. sakmaricus } & Cy. lapworthi & Cy. sakmaricus \\
\hline & \multicolumn{2}{|c|}{ O. spiralis } & O. spiralis & O. spiralis \\
\hline & \multirow{2}{*}{\multicolumn{2}{|c|}{$\begin{array}{l}\text { Mcl. crenulata/ } \\
\text { Mcl. griestoniensis }\end{array}$}} & Mcl. crenulata & Tor. tullbergi \\
\hline & & & Mcl. griestoniensis & Mcl. griestoniensis \\
\hline & \multirow{2}{*}{\multicolumn{2}{|c|}{ Str. crispus }} & Str. sartorius & \multirow{2}{*}{ Str. crispus } \\
\hline & & & Str. crispus & \\
\hline & \multicolumn{2}{|c|}{ Sp. turriculatus } & Sp. turriculatus & Sp. turriculatus \\
\hline & \multicolumn{2}{|c|}{ Sp. guerichi } & Sp. guerichi & R. linnaei \\
\hline \multirow{6}{*}{$\frac{\frac{\sigma}{\frac{\pi}{0}}}{\frac{0}{\frac{0}{0}}}$} & \multirow{2}{*}{\multicolumn{2}{|c|}{ Sti. sedgwickii }} & Sti. halli & \\
\hline & & & Sti. sedgwickii & Sti. sedgwickil \\
\hline & \multicolumn{2}{|c|}{ Lit. convolutus } & Lit. convolutus & Lit. convolutus \\
\hline & \multirow{3}{*}{ 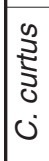 } & \multirow{2}{*}{ R. orbitus } & Pr. leptotheca & Pr. leptotheca \\
\hline & & & Neo. $r$ & M. simulans \\
\hline & & $\begin{array}{l}\text { D. pectinatus/ } \\
\text { D. triangulatus }\end{array}$ & M. triangulatus & $\begin{array}{l}\text { D. pectinatus/ } \\
\text { D. triangulatus }\end{array}$ \\
\hline \multirow{2}{*}{$\begin{array}{l}\frac{\dot{\partial}}{2} \\
\frac{\hat{\tau}}{\simeq}\end{array}$} & \multicolumn{2}{|c|}{ Cor. cyphus } & M. revolutus & Cor. cyphus \\
\hline & \multicolumn{2}{|c|}{ Hut. acinaces } & Hut. acinaces & Cyst. vesiculosus \\
\hline
\end{tabular}

Figure 2. Llandovery (mid-Rhuddanian - upper Telychian) biostratigraphic scheme for Arctic Islands, and comparison with those of the Great Britain and Peri-Gondwana (in particular, Czech Republic). Abbreviations of generic names: $\quad C o r .=$ Coronograptus,$\quad C y .=$ Cyrtograptus,$\quad D .=$ Demirastrites, Hut. $=$ Huttagraptus, Lit. $=$ Lituigraptus, M. = Monograptus, Mcl. $=$ Monoclimacis, $O .=$ Oktavites,$\quad P r .=$ Pristiograptus,$\quad R .=$ Rastrites,$\quad S p .=$ Spirograptus, Sti. $=$ Stimulograptus, Str. $=$ Streptograptus, Tor.$=$ Torquigraptus.

Pseudoretiolites.-Historically, the oldest known records of retiolitine graptolites globally are those of species of Pseudoretiolites Bouček and Münch, 1944, particularly $P$. perlatus (Nicholson, 1868), from the upper part of the Coronograptus gregarius Zone (lower Aeronian-Elles and Wood, 1908; Bouček and Münch, 1944), and in strata of the upper part of their lower Aeronian Demirastrites triangulatus Zone in association with Demirastrites pectinatus (Obut and Sobolevskaya,1968). However, more recent compilations of graptolite biostratigraphic occurrences in the United Kingdom (Rickards, 1976; Zalasiewicz et al., 2009) showed the oldest retiolitine taxon, $P$. perlatus, occurring no lower than the Lituigraptus convolutus Zone. A detailed study of the mid-Aeronian strata in the Czech sequence by Štorch (1998) showed that $P$. perlatus commonly occurs in the L. convolutus Zone, but that it also occurs rarely in the underlying Pribylograptus leptotheca and Demirastrites simulans zones (= Rastrites orbitus Subzone of Arctic Canada). Other species of Pseudoretiolites, such as P. decurtatus Bouček and Münch, 1944, and P. tianbaensis Ge, 1990 from China, first occur in most studies no lower than the L. convolutus Zone (e.g., Obut and Sobolevskaya, 1967; Štorch, 1998; Ge, 1990), or in the lowest Telychian Spirograptus guerichi and Spirograptus turriculatus zones (e.g., Bouček and Münch, 1944; Münch, 1952; Chen, 1984), although Lenz and Melchin (1987a) and Melchin (1989) recorded P. cf. decurtatus in the upper Campograptus curtus Zone in Arctic Canada. Although some summary range figures show Pseudoretiolites appearing at the base of the Aeronian (e.g., Lenz and Melchin, 1997, fig. 4; 


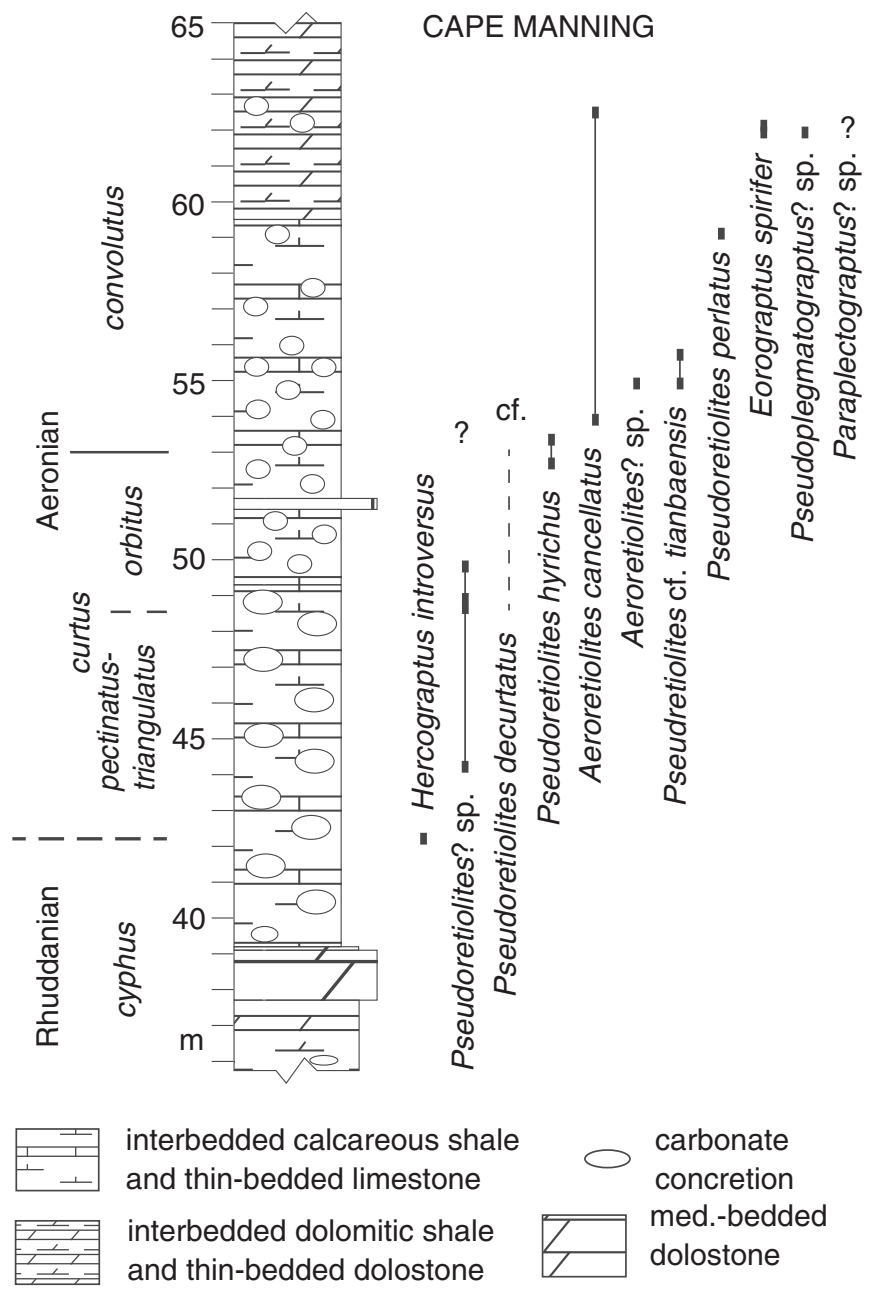

Figure 3. Lithological log through the upper Rhuddanian to mid-Aeronian part of the Cape Manning section, Cornwallis Island, showing graptolite zonation and stratigraphic levels of occurrence of graptolite taxa referred to in this study. Dashed line indicates approximate stratigraphic level of taxon occurring in an unmeasured reconnaissance sample collected at this locality (see Appendix 1).

Kozłowska-Dawidziuk, 2004, fig. 1), the previously known occurrence data summarized here point to the fact that this genus appeared within the lower Aeronian, but not at its base, and was relatively common in at least the mid and upper Aeronian globally.

Our new data demonstrate that the Arctic Canadian sequence yields several species of Pseudoretiolites occurring in the upper part of the lower and the mid Aeronian. In addition, we document one unnamed species assigned to Pseudoretiolites? from the lower Aeronian. It appears therefore, that Arctic Canada may be the only region globally where retiolitines can be confidently recognized from lowest Aeronian strata. Unfortunately, because only the early developmental stages of these earliest Arctic specimens are well preserved, positive determination of the genus and species is not possible.

Pseudoplegmatograptus.-The second long-known and globally widespread genus of the Aeronian-lower Telychian is Pseudoplegmatograptus Př́byl, 1948. This genus has been most commonly reported from strata no lower than the $S$. guerichi or
S. turriculatus zones (lower Telychian) (e.g., Bouček and Münch, 1944; Münch, 1952; Schauer, 1971; Hutt, 1974; Bjerreskov, 1975; Rickards, 1976; Chen, 1984; Ge, 1990; Tomczyk et al., 1991; Loydell, 1993; Lenz et al., 2003), although Zalasiewicz et al. (2009) recorded a possible occurrence of Pseudoplegmatograpus from the S. sedgwickii Zone in UK (based on Hutt, 1974), and occurrences in the Stimulograptus halli Zone (uppermost Aeronian), continuing into the lower Telychian. In addition, Lenz (1982) reported Pseudoplegmatograptus obesus from the $S$. sedgwickii Zone in northwestern Canada, as well as a single unillustrated specimen assigned to $P$. cf. obesus from the L. convolutus Zone.

Pseudoplegmatograptus obesus occurs in the lower Telychian S. guerichi Zone in Arctic Canada and is, thus far, the only species of this genus recognized from the lower-mid Telychian strata in that region. We also report the occurrence of an incompletely preserved, unnamed species questionably assigned to Pseudoplegmatograptus in the L. convolutus Zone in Arctic Canada.

Two other species of this genus were reported from the uppermost Telychian by Melchin (1989), although one of those species, Pseudoplegmatograptus giganteus, was named as the type species of a new genus, Giganteograptus, by Lenz and Kozłowska (2007).

Li (1995) reported two species of Pseudoplegmatograptus from strata assigned to the Coronograptus cyphus Zone in China. Although this zone is normally considered to be upper Rhuddanian in age, the co-occurrence of species of Petalolithus and Rastrites along with retiolitines indicates that at least part of this zone is Aeronian (but not lowest Aeronian) in age. Chen and Lin (1978) also reported specimens of Pseudoplegmatograptus from the lower Aeronian in China. Illustrations of the material assigned to Pseudoplegmatograptus by both Li (1995) and Chen and Lin (1978) show that the specimens are incomplete and not well preserved and they could represent specimens of Pseudoretiolites rather than Pseudoplegmatograptus (Loydell, 1993). Further study of these specimens is required.

Eorograptus.-Eorograptus Sennikov, 1984 was originally described from strata of the Spirograptus minor (=S. guerichi) Zone in Siberia (Sennikov, 1976, 1984). A new species of this genus is now recorded herein from the L. convolutus Zone in Arctic Canada.

Rotaretiolites.-Rotaretiolites, first identified as "Retiolites sensu lato sp." by Hutt et al. (1970, pl. 1, figs. 19, 20) from Swedish material, was later named and described by Bates and Kirk (1992), based on different specimens from the same Swedish locality. This genus was subsequently illustrated from Arctic Canada (see Kozłowska-Dawidziuk and Lenz, 2001, fig. 3.11). All reports of this genus, including the present material, are from the $S$. guerichi-S. turriculatus zonal interval.

Other taxa.- In this paper, we document one (possibly two) species of a new genus, Aeroretiolites, from the L. convolutus Zone, which bears many close morphological similarities with Rotaretiolites, and the two genera may represent part of the same lineage (see Phylogenetic analysis, below). 
We also document an unnamed species questionably assigned to Paraplectograptus. The fact that this taxon occurs in the S. guerichi Zone, and possibly the L. convolutus Zone, is important because it may represent both a temporal and phylogenetic link between typical Aeronian forms and the more derived taxa that have been commonly regarded as "plectograptines" in later Telychian and younger strata.

\section{Phylogenetic analysis}

Much of the history of our understanding of the phylogeny and systematics of retiolitines was summarized by Lenz and Melchin (1997) and Bates et al. (2005). Those two papers both presented phylogenetic analyses of retiolitines based on different sets of taxa and character state codings. In particular, the Lenz and Melchin (1997) study included data from some new Aeronian species described in this study, but Bates et al. (2005) focused primarily on Wenlock and Ludlow taxa and did not include all of the taxa analyzed by Lenz and Melchin (1997). The results of those two cladistics analyses suggested very different patterns of emergence of those taxa traditionally assigned to the Retiolitinae (e.g., Pseudoplegmatograptus, Stomatograptus and Retiolites) and the Plectograptinae (e.g., Paraplectograptus, Sokolovograptus and Plectograptus), as well as conflicting interpretations about the relationship of Rotaretiolites to these two groups. One of the objectives of this study was to use all of new data available from the study of these newly described Aeronian and early Telychian faunas, together with a new character coding set incorporating information from all of the previous studies, to test these different hypotheses of the relationships among Llandovery retiolitines.

Selection of taxa and characters.-Our phylogenetic analysis focuses on the Aeronian and early Telychian retiolitines that were recovered from the Cape Phillips Formation and are systematically described in this paper: Pseudoretiolites perlatus, P. decurtatus, P. hyrichus, Pseudoretiolites? sp., Pseudoplegmatograptus obesus, Rotaretiolites exutus, Rotaretiolites cf. exutus, Eorograptus spirifer, Aeroretiolites cancellatus, Aeroretiolites? sp., and Paraplectograptus? sp. In addition, to understand the phylogenetic relationships between our relatively early retiolitine forms and some later Telychian taxa that have been included in previous phylogenetic studies, we included the following later Llandovery taxa: Retiolites geinitzianus Barrande, 1850, Stomatograptus canadensis Lenz, 1988, Paraplectograptus eiseli (Manck, 1917), and Sokolovograptus textor (Bouček and Münch, 1952). We have also included Pseudorthograptus obuti (Rickards and Koren', 1974), P. inopinatus (Bouček, 1944) (Fig. 4), and Hercograptus introversus Melchin, 1999, as the most closely related representatives of the Petalolithinae (Melchin et al., 2011) for comparison and testing the hypothesis of the monophyly of the Retiolitinae. Separate analyses were run with each of these three taxa as the outgroup.

We have not included Pseudoretiolites cf. tianbaensis, described in this paper, in our analysis because too little is known of its internal structure and proximal development for reliable coding. In addition, since Pseudoretiolites decurtatus and $P$. perlatus differ only in minor quantitative parameters, they showed no differences that were captured by our

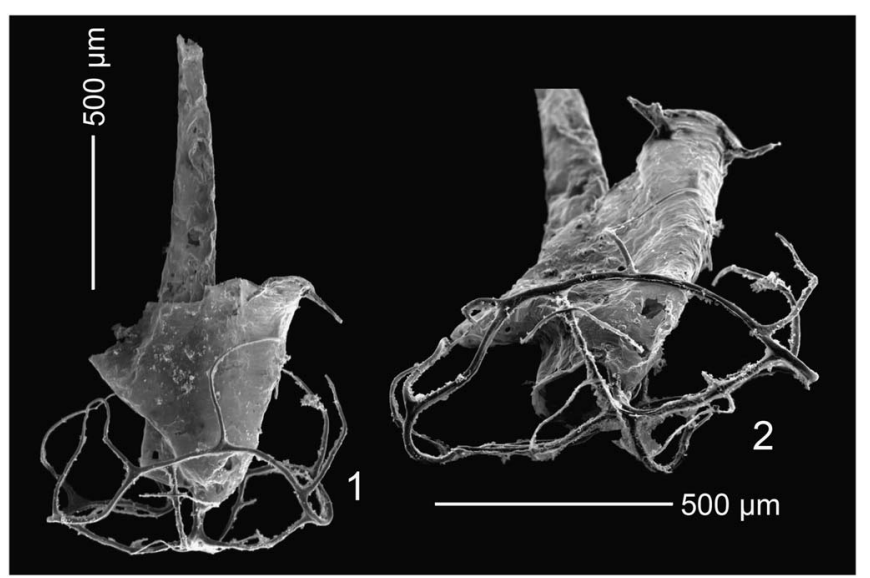

Figure 4. Scanning electron microscope images of Pseudorthograptus inopinatus (Bouček, 1944), GSC137621, early growth stage specimen showing well-preserved ancora umbrella: (1) profile view of complete specimen; (2) oblique proximal end view showing broken, but otherwise wellpreserved spiral lists on the shallow ancora umbrella, unknown locality, Cornwallis Island, C. curtus or lower L. convolutus Zone.

coding system. Of the two species, Pseudoretiolites perlatus was included in the analysis because the structure of its proximal end is better preserved in our material. The two taxa can be regarded as sister species, more closely related to each other than any other taxa in our analysis.

The characters and their states that we have used are modified after Bates et al. (2005) to accommodate the features specifically seen among our study taxa. We have simplified the coding of ancora types to reflect the lesser degree of variation seen among our earlier study species. As a result, our coding of ancora types more closely reflects that of Lenz and Melchin (1997). The list of characters and their states is presented in Appendix 2, which also provides the sources of the morphological information for taxa not described in this study. The matrix showing the taxa and their character states is shown in Table 1.

We conducted one analysis in which all characters were unordered and another in which the following characters were ordered: 4-prosicula preservation; 5-metasicula preservation. The analysis using all unordered characters produced a better-resolved tree and used no a priori assumptions about character directionality, so we present here only the results of the analysis using all unordered characters.

Cladistic analysis methods.-Preparation of the data matrix and analysis of the trees resulting from the parsimony searches were conducted using MacClade 4.06 (Maddison and Maddison, 2003). The branch-and-bound parsimony searches and bootstrap analyses were conducted using PAUP*4.10b (Swofford, 2002). Initial analyses used all equally weighted characters. Based on these analyses the character weights were recalculated using the rescaled consistency index (RCI). The rationale for this approach was extensively outlined by Donoghue et al. (2008 and references therein), and this methodology was also employed by Melchin et al. (2011). After a second analysis, the character weights were again recalculated using the RCI, and run again. After this point, further re-analyses produced no additional change in RCIs 
Table 1. Matrix of characters and character states for each taxon in the cladistic analysis.

\begin{tabular}{lllllllllllccccccccccc}
\hline Genus species & 1 & 2 & 3 & 4 & 5 & 6 & 7 & 8 & 9 & 10 & 11 & 12 & 13 & 14 & 15 & 16 & 17 & 18 & 19 & 20 \\
\hline Pseudorthograptus obuti & 0 & 0 & 0 & 0 & 0 & 0 & 0 & - & 0 & 0 & 1 & 1 & 0 & 0 & $?$ & 1 & 0 & 0 & 0 & 0 \\
Pseudorthograptus inoptinatus & 0 & 1 & 0 & 0 & 0 & 0 & 0 & - & 0 & 0 & 0 & 1 & 0 & 0 & - & 1 & 0 & 0 & 1 & 1 \\
Hercograptus introversus & 0 & 0 & 0 & 0 & 0 & 0 & 0 & 0 & 1 & 1 & 1 & 1 & 0 & 0 & 1 & 0 & 1 & $?$ & 0 & 0 \\
Pseudoretiolities? sp. & 0 & 0 & 1 & 0 & 0 & 1 & 0 & 0 & 1 & 1 & 1 & 0 & 0 & $?$ & 1 & 0 & 1 & $?$ & $?$ & 0 \\
Pseudoretiolites perlatus & 0 & 0 & 1 & 1 & 1 & 1 & 0 & 2 & 1 & 1 & 1 & 0 & 0 & 1 & 1 & 0 & 1 & 1 & 0 & 0 \\
Pseudoretiolites hyrichos & 0 & 0 & 2 & 0 & 1 & 1 & 0 & 2 & 1 & 1 & 1 & 0 & 0 & 1 & 1 & 0 & 1 & 1 & 1 & 1 \\
Pseudopelgmatograptus obesus & 2 & 1 & 2 & 0 & 2 & 1 & 0 & 3 & 1 & 0 & 1 & 0 & 0 & 1 & 1 & 1 & 1 & 1 & 0 & 0 \\
Stomatograptus canadensis & 2 & 1 & 1 & 1 & 2 & 1 & 0 & 3 & 0 & 0 & 1 & 0 & 0 & 1 & 1 & 0 & 1 & 1 & 0 & 0 \\
Retiolites geinitzianus & 2 & 1 & 1 & 1 & 2 & 1 & 0 & 3 & 0 & 0 & 1 & 0 & 0 & 0 & 1 & 0 & 1 & 1 & 0 & 0 \\
Aeroretiolites cancellatus & 0 & 1 & 2 & 1 & 2 & 1 & 1 & 1 & 1 & 0 & 1 & 0 & 0 & 0 & 0 & 0 & 1 & 1 & 1 & 1 \\
Aeroretiolites? sp. & 1 & 1 & 2 & $?$ & 2 & 1 & 1 & 1 & 1 & 0 & 0 & 0 & 0 & - & - & 0 & 1 & 1 & 1 & 1 \\
Rotaretiolites cf. exutus & 1 & 1 & 2 & 2 & 2 & 1 & 1 & 1 & 1 & 0 & 0 & 0 & 1 & - & - & 1 & 0 & 0 & 1 & 1 \\
Rotaretiolites exutus & 1 & 1 & 2 & 2 & 2 & 1 & 1 & 1 & 1 & 0 & 0 & 0 & 1 & - & - & 0 & 0 & 0 & 1 & 1 \\
Eorograptus spirifer & 0 & 1 & 2 & 0 & 2 & 1 & $?$ & 3 & 0 & 0 & 0 & 0 & 0 & - & - & 0 & 1 & 1 & 1 & 1 \\
Paraplectograptus? sp. & 1 & 1 & 2 & 0 & 2 & 1 & $?$ & 3 & $?$ & 0 & 1 & 0 & 0 & 0 & 0 & 0 & 1 & 1 & $?$ & $?$ \\
Paraplectograptus eiseli & 1 & 1 & 2 & 3 & 2 & 1 & $?$ & 3 & 0 & 0 & 1 & 0 & 2 & 0 & 0 & 0 & 1 & 1 & 1 & 1 \\
Sokolovograptus textor & 1 & 1 & 2 & 3 & 2 & 0 & 2 & 3 & 0 & 0 & 1 & 1 & 2 & 0 & $0 \& 1$ & 0 & 1 & 1 & 1 & 1 \\
\hline
\end{tabular}

or tree length. Bootstrap analyses were conducted using 1000 replicates.

We also conducted a parsimony analysis on this matrix using TNT (Tree Analysis using New Technology, see Goloboff et al., 2008). Using TNT it is possible to conduct a search using implied weighting (IW-rather than reiterative weighting as is done in PAUP*), which seeks to simultaneously maximize character consistency while minimizing tree length (e.g., Mitchell et al., 2013). In addition, TNT permits calculation of additional measures of node support, such as Bremmer support and relative Bremmer support.

Results and discussion of cladistic analysis.-Both the PAUP* and TNT analyses with all characters unweighted and unordered resulted in a single most parsimonious tree (MPT, Fig. 5.1). Analyses with weighted characters also produced single MPTs with the same topology. Although we experimented with a range of $\mathrm{K}$ values in the IW analysis (see Goloboff et al., 2008; Mirande, 2009), varations in $\mathrm{K}$ values produced no differences in the tree topology. A list of the character state changes at each of the nodes in the cladogram is included in Appendix 3. A comparison of some of the tree statistics for the analyses using both unweighted and reweighted characters, as calculated from the PAUP* analyses, are: tree length, unweighted 51, weighted 22.3; consistancy index, unweighted 0.569, weighted 0.734; retention index, unweighted 0.722 , weighted 0.835 ; homoplasy index, unweighted 0.431 , weighted 0.266 .

Although the trees with unweighted characters were resolved to a single MPT, the levels of support for most of the nodes was low. Only nodes $0,1,10$, and 13 showed both bootstrap support $>60 \%$ and Bremmer support $>1$. The analyses using reweighed characters in PAUP* and IW in TNT showed better support for many of the nodes (Fig. 5.1). Figure 6 shows a proposed phylogenetic tree based on the cladogram and the known stratigraphic ranges of the taxa.

Several features are evident from these results. Despite the inclusion of two different species of Pseudorthograptus that possess different tubaria forms and ancora depths, our results show that all of the taxa commonly included within the Retiolitinae (sensu Melchin et al., 2011) form a clade with relatively good support no matter which taxon is chosen as the outgroup. Hercograptus introversus is sister to the retiolitine clade, as proposed by Melchin (1999).

Our analyses show that species here assigned to Hercograptus, Pseudoretiolites? sp. and Pseudoretiolites form a stem lineage for two sister clades, one including Pseudoplegmatograptus, Retiolites, and Stomatograptus, and the other including all other taxa in the study group. The latter clade, which includes our coded species of Paraplectograptus and Sokolovograptus, is almost certainly the root of the clade that includes all more derived "plectograptines" (Lenz and Melchin, 1997; Bates et al., 2005). There is support for the suggestion that Pseudoretiolites? sp. is primitive with respect to all other retiolitines.

As noted above, there is some support for the hypothesis of Lenz and Melchin (1997) that the species of Pseudoplegmatograptus, Retiolites, and Stomatograptus form a clade, which Lenz and Melchin assigned to the Retiolitinae. This contrasts with the results of Bates et al. (2005, fig. 8B), who found that those taxa formed a poorly resolved, paraphyletic group. Their analysis also showed Rotaretiolites branching from the near the base of the cladogram, sister to all of the other taxa normally included among the retiolitines. However, their analysis did not include the taxa here assigned to Aeroretiolites and Eorograptus and had some differences in character coding.

To test whether the differences between our results and those of Bates et al. (2005) are the result of inclusion of different taxa, differences in character coding, or both, we conducted an analysis in PAUP* using only the taxa that were in both our analysis and that of Bates et al. The only Llandovery taxon included in the Bates et al. analysis that was not included in ours was Dabashanograptus, which, in their analysis, occurred at a polytomy with Retiolites, Stomatograptus, and the more derived "plectograptines" (Bates et al., 2005, fig. 8B). The result of our analysis was a poorly resolved consensus of five MPTs (Fig. 5.2). This result indicates that although the addition of our new taxa to the analysis clearly helps to better resolve the relationships among the taxa in a manner more consistent with their known stratigraphic distribution (Figs. 5.1, 6), the differences in position of Rotaretiolites in the tree appear to be mainly the result of differences in character coding. 


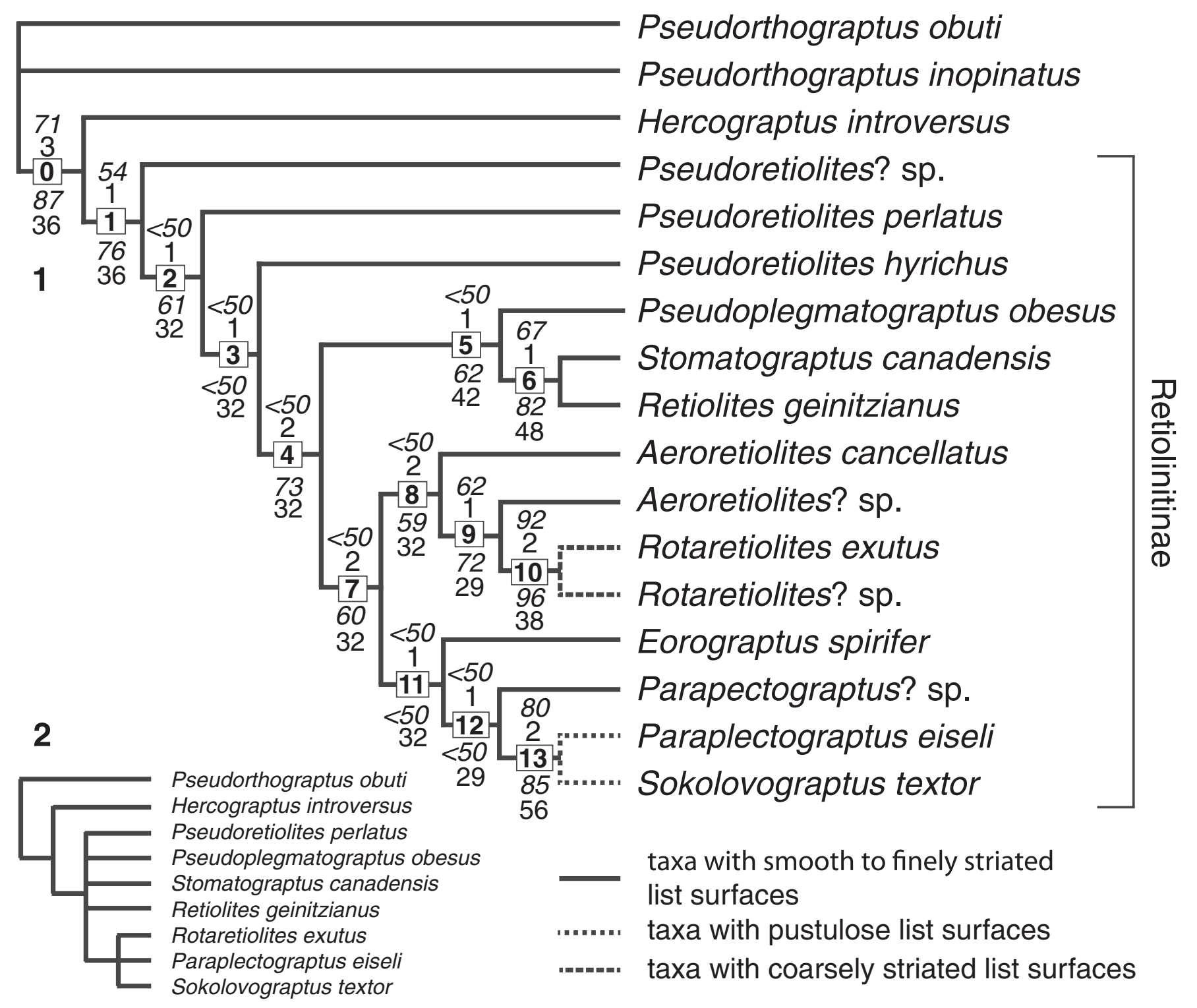

Figure 5. (1) Cladogram of single most parsimonious tree resulting from the analyses that included all taxa in our study and all characters unordered. Bold numbers in square boxes are numbered nodes. Character state changes at each node are listed in Appendix 3. Numbers in italics shown above each of the nodes are levels of bootstrap support for those branches (from PAUP*) from the analysis in which characters were unweighted. Numbers in italics below the nodes are levels of bootstrap support (from PAUP*) from the analysis in which characters were reweighted by rescaled consistency index. Numbers not in italics above the nodes are Bremmer support values from the unweighted analysis from TNT and those below are relative Bremmer support values from the implied weighting analysis from TNT. The species of Pseudorthograptus and Hercograptus are members of the Petalolithinae of Melchin et al. (2011), the remaining taxa are assigned to the Retiolitinae sensu Melchin et al. (2011). (2) Results of the unweighted analysis in PAUP* including only those taxa from this analysis that were also included in the analyses of Bates et al. (2005). This is a strict consensus of five most parsimonious trees.

Our results indicate that there is consistent support for the hypotheses of both Lenz and Melchin (1997) and Bates et al. (2005) that Paraplectograptus and Sokolovograptus form a clade. In addition, this group is derived from within a less strongly supported clade that also includes Rotaretiolites and the species that we here assign to Aeroretiolites, Eorograptus, and Parapectograptus? sp. (i.e., "Rotaretiolites," "Paraplectograptus," and Paraplectograptus 1 of Lenz and Melchin, 1997, respectively). In particular, there is some evidence that Eorograptus and Parapectograptus? sp. share a common ancestry with Paraplectograptus and Sokolovograptus, separately from Rotaretiolites and Aeroretiolites. There is also evidence for the suggestion that these last two genera form a clade and the former is more derived with respect to the latter.
Our results indicate that Paraplectograptus? sp. does not differ in any of our coded characters from the common ancestor of Paraplectograptus and Sokolovograptus. Likewise, Aeroretiolites? sp. does not differ in any of our coded characters from the ancestor of Rotaretiolites, Stomatograptus canadensis does not differ in any of our coded characters from the common ancestor of Stomatograptus and Retiolites, and Pseudoretiolites? sp. does not differ in any of our coded characters from the common ancestor of all of the more derived retiolitines. Given the general scarcity of other detailed morphologic and biostratigraphic information about Aeronian retiolitines, however, more definitive inferences cannot be made about ancestral relationships among the known taxa. 


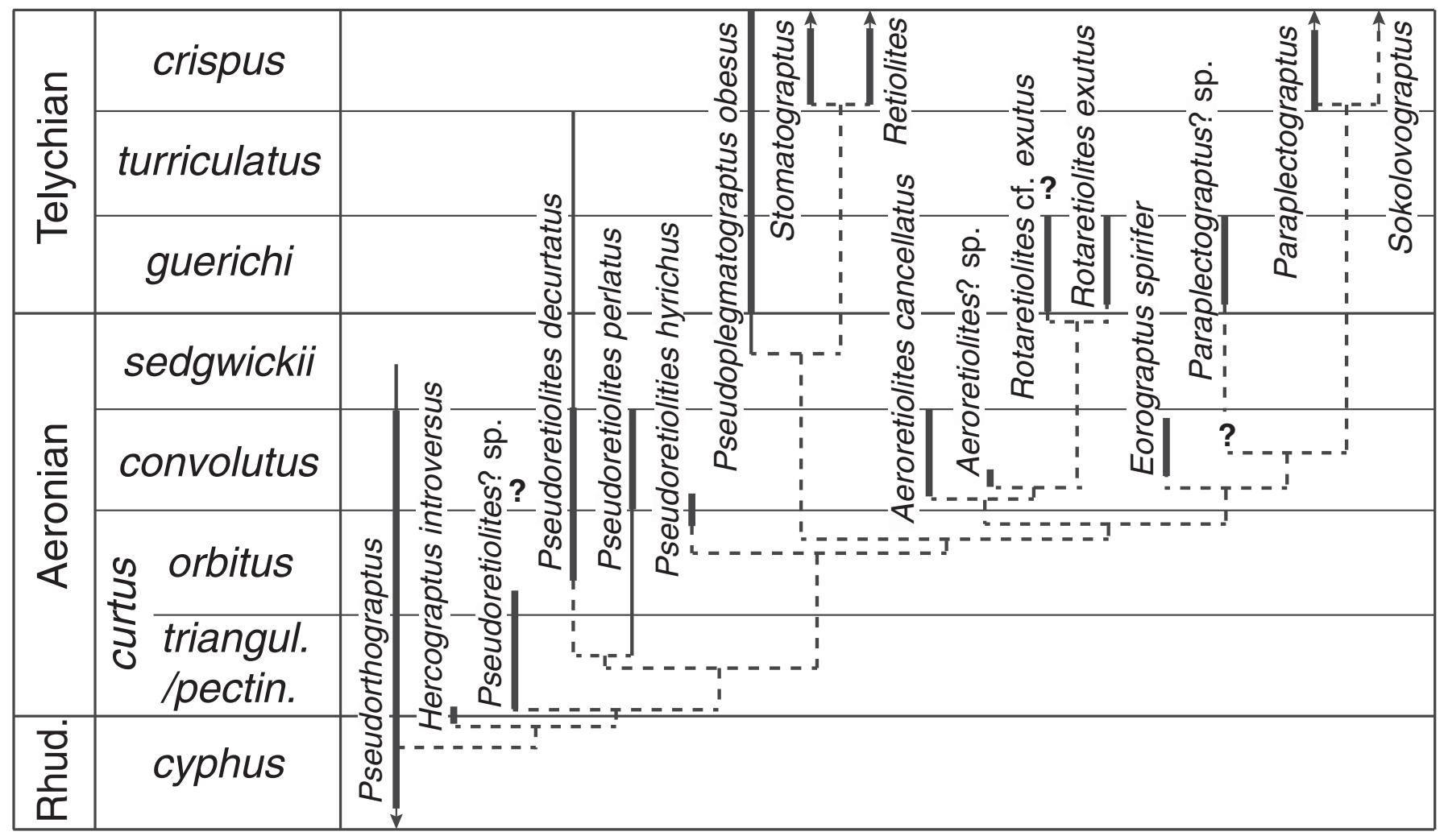

Figure 6. Proposed phylogenetic tree based on cladogram depicted in Figure 5 and known taxonomic ranges of the taxa. Thick solid lines are ranges observed in Arctic Canada, thin solid lines are additional ranges observed in other regions. Dashed lines indicate proposed phylogenetic relationships. Note that Pseudoretiolites decurtatus was not included in the cladistics analysis because its coding was identical to that of $P$. perlatus. The two are therefore regarded as a sister species. See text for further discussion. Note that Pseudorthograptus and Hercograptus are members of the Petalolithinae of Melchin et al. (2011), the remaining taxa are assigned to the Retiolitinae.

\section{Implications for family-level taxonomy}

The present study brings into sharp focus the problem of the status of family-level subdivision within the "retiolitids". Beginning with Bouček and Münch (1952), the retiolitids were divided into the subfamilies Retiolitinae (older) and Plectograptinae (younger) (see also Bulman, 1970), based mainly on the chronostratigraphic position of the known taxa and their overall morphological complexity. With the advent of electron microscopic studies of isolated material, Lenz and Melchin (1987a) continued with the twofold division, but focussed on the type of list micro-ornament on bandages; i.e., parallel striae for the former and pustules for the latter. Lenz and Melchin (1997) published the first cladistic study of all the then-known retiolitid genera, and proposed, based on phylogenetic branching relationships, that the Plectograptinae should be expanded to include some taxa with parallel striae on the lists rather than pustules. Unfortunately, those authors did not revise the diagnosis of the Plectograptinae to reflect this revised concept of the taxon. Maletz (2014) has maintained the taxonomic distinction between the Retiolitinae and Plectograptinae based on their list ornamentation.

The present cladistic study, focussing on only Llandovery taxa (Fig. 5.1), arrives at essentially the same clade relationships as proposed by Lenz and Melchin (1997) and demonstrates that the simple twofold division into the subfamilies Retiolitinae and Plectograptinae, based on list ornamentation, is not consistent with the phylogenetic relationships among the species. In particular, including all and only those species with non-pustulose lists in the Retiolitinae results in a taxon that contains the stem taxon Pseudoretiolites, the clade that includes Pseudoplegmatograptus, Stomatograptus, and Retiolites, and part (but not all) of the clade that includes Aeroretiolites, Rotaretiolites, Paraplectograptus, and Sokolovograptus (pustulose list ornamentation appears at node 13 in Fig. 5.1 and is only seen in Paraplectograptus eiseli and S. textor in our study). This is not a good reflection of the phylogeny of this group of genera. We propose therefore, that

Figure 7. Scanning electron microscopy images of Pseudoretiolites cf. tianbaensis (Ge, 1990): (1, 2) GSC137626, (1) stereopair of mature specimen with at least six thecae and three stomata, (2) enlargement showing partially preserved ancora umbrella with three or four spiral whorls, section LL1B, S. guerichi or S. turriculatus Zone; (3) GSC137627, stereopair of partially preserved specimen without ancora umbrella, LL1-77, S. guerichi Zone?; (4, 5) GSC137628, (4) proximal region, showing well-preserved umbrella with four spiral whorls, (5) enlargement of ventral wall of theca $1^{1}$, showing robust thecal lip (a) and 'pseudolip' (b), section MSC07, 3 m above 01G, S. guerichi Zone?; (6) GSC137631, proximal specimen with partially preserved umbrella with four (?) spiral whorls and two pairs of thecae, section SJF02, 1C, S. guerichi Zone?; (7, 8) GSC137630, (7) enlargement showing thecal lips underlain by a looped pseudolip (arrows), (8) stereopair of latero-ventral view of specimen with five pairs of thecae, showing robust, zigzag thecal ventral walls underlain by a somewhat lacy pseudolip, section MSC07, $3 \mathrm{~m}$ above 01G, S. guerichi Zone?. 
(2)

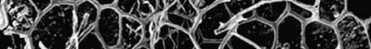
30.25

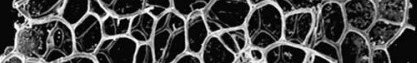
- a 2 . 21 7. Jo $2020 ?$

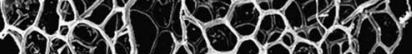

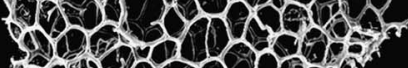
10.420200 toron 1021000 $10200 \%$ 16325120 9001000 101020. Q 10000 592020

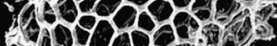
$1>020 \%$ - 2090 . 12002 10201 1. 12

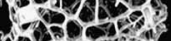
(1) 519 25ing

\section{a.}

n. Y 00003 0000120 - 20.01003.

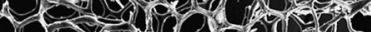
* 10 rar - 000025 - -100 cosor $1021-1000$. 200000 18002001 ? 301908 on? 20 (1) 12 nanaris 40 10 .

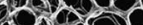
cros- 00 groes. \& 3

\section{Rn} Dons

542,0100

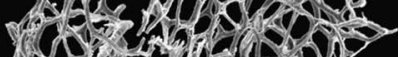

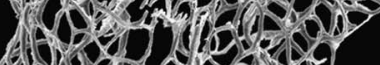
wandore 00000020

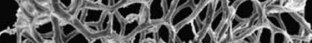

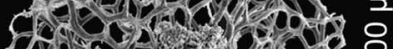

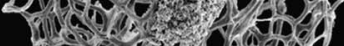
d 30015009

Gro way a es
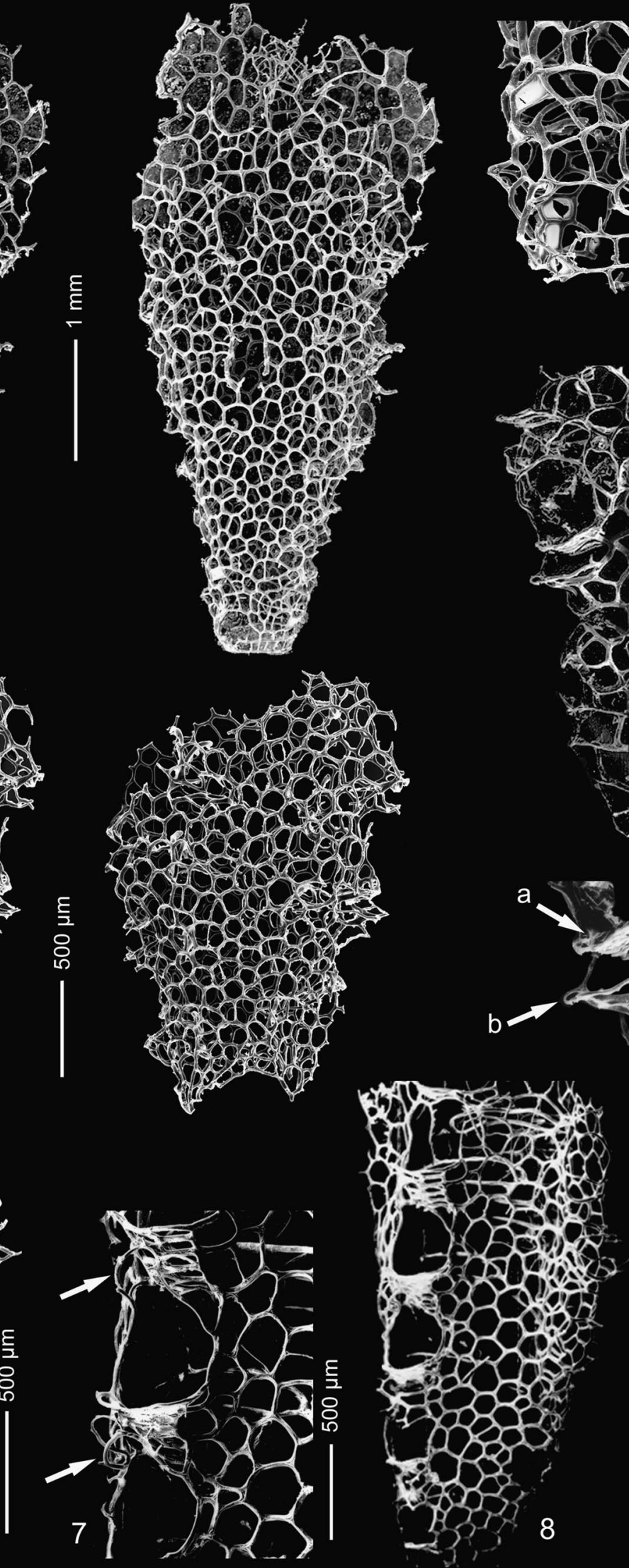

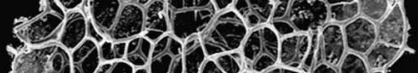

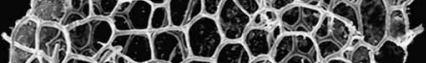
a 10125 7221201 201 12000114

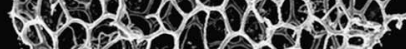
121200 - $10 \times 12$ $42010-120$ 1002025

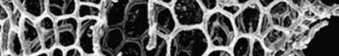

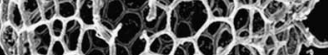
100 2a 2 . - 050300 1000000 10912 2. 102093 014 102013 1700 1020 1203

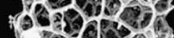
tos 3 : 9.2 $7808 \%$ 1.
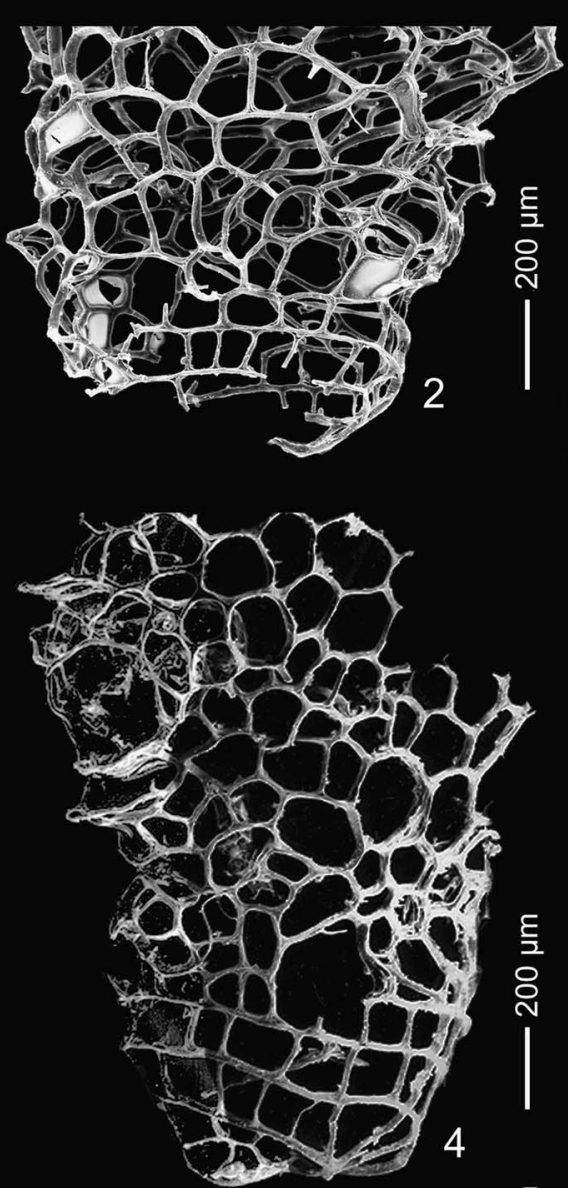

틀 
the most parsimonious solution is to follow Melchin et al. (2011) and assign the entire retiolitid group (the clade above node 1) to the subfamily Retiolitinae. If further subdivision of this subfamily were to be proposed (at the level of tribe), we suggest that it should reflect the sister-group status of the two clades that include Pseudoplegmatograptus, Stomatograptus, and Retiolites on the one hand, and Aeroretiolites, Eorograptus, Rotaretiolites, Paraplectograptus, Sokolovograptus, and their "plectograptine" descendants on the other, as well as the paraphyletic, stem-group status of Pseudoretiolites (Fig. 5.1).

\section{Retiolitine diversity and disparity in the Llandovery}

Our data provide important new insights into the pattern of diversification of the Retiolitinae in Aeronian and early Telychian time (Figs. 3,6). In particular, our data show that at least eight different retiolitine species belonging to four different genera occur within the L. convolutus Zone, whereas previously only two species of Pseudoretiolites had been identified with certainty from from this interval. We show that a significant disparity of retiolitine forms, ranging from large and complex species, such as Pseudoretiolites decurtatus, to the small and highly simplified form of Eorograptus spirifer, already existed by mid-Aeronian time.

As noted above, there have been almost no graptolites recovered from the $S$. sedgwickii Zone in Arctic Canada, despite considerable sampling effort. This appears to be the result of unfavourable preservational conditions in this interval (including a lack of concretions), which means that the lack of retiolitine species discovered in that interval in this study is clearly a taphonomic artefact. Our data, therefore, provide no new insights into the details of changing retiolitine faunas through the sedgwicki extinction event that characterizes the late Aeronian (e.g., Melchin et al., 1998; Štorch and Frýda, 2012). Our study does, however, provide data that allow us to reconstruct the phylogeny of retiolitine lineages through this time interval (Fig. 6).

The morphology of many retiolitine species that occur in later Llandovery-Wenlock strata have been described and illustrated by Lenz and Melchin (1987a), Lenz and KozłowskaDawidziuk (2001), Kozłowska-Dawidziuk and Lenz (2001), Lenz and Kozłowska (2007), and Lenz et al. (2012). Melchin (1989) documented the ranges of retiolitines through the Llandovery of Arctic Canada based on flattened material. These studies, together with our additional unpublished data, show that the following genera occur in mid-late Telychian strata in Arctic Canada: Retiolites Barrande, 1850, Stomatograptus Tullberg, 1883, Paraplectograptus Př́ibyl, 1948, Pseudoplectograptus Obut and Zaslavskaya, 1983, Sokolovograptus Obut and
Zaslavskaya, 1983, Pileograptus Lenz and Kozłowska, 2007, and Giganteograptus Lenz and Kozłowska, 2007. Detailed SEM studies on Retiolites and Stomatograptus from Arctic Canada have been carried out by Bates and Kirk (1997).

\section{Locality and repository information}

All of the material used in the present study has been chemically isolated from calcite concretions and studied using stereopair scanning electron microscopy (SEM) images. Much of the material was collected from from Cape Manning (Figs. 1, 3; CM $\left.75^{\circ} 27^{\prime} \mathrm{N}, 94^{\circ} 21^{\prime} \mathrm{W}\right)$. Additional material came from Rookery Creek, Cornwallis Island ( $\mathrm{RC} 75^{\circ} 22.5^{\prime} \mathrm{N}, 95^{\circ} 41^{\prime} \mathrm{W}$ ), Snowblind Creek, Cornwallis Island (SC $75^{\circ} 11^{\prime} \mathrm{N}, 93^{\circ} 56^{\prime} \mathrm{W}$ ), Dundas Island ( $\left.76^{\circ} 05^{\prime} \mathrm{N}, 95^{\circ} 59^{\prime} \mathrm{W}\right)$, Cape Sir John Franklin, Devon Island (SJF $76^{\circ} 42.5^{\prime} \mathrm{N}, 96^{\circ} 53^{\prime} \mathrm{W}$ ), and an unknown locality on Cornwallis Island. See Appendix 1 for further sample details.

Illustrated specimens are given Geological Survey of Canada (GSC) numbers, and are housed with The National Collection of Invertebrate and Plant Fossils of the Geological Survey of Canada, Ottawa, K1A 0E8.

Collection localities and abbreviations are as follows: Cape Manning (MCM; CM88), Snowblind Creek (LL1 and LL3; MSC; ML64-85; SB), and Rookery Creek (MRC), all three from Cornwallis Island (see Fig. 1). The other two localities are Cape Sir John Franklin (SJF) on westernmost Devon Island, and Dundas Island (DIS).

\section{Systematic paleontology}

Throughout the Systematics section, for species with numerous synonymies, only the original type publication and those considered to be the most informative are listed. Morphological terminology follows that outlined by Bates et al. (2005) and the family-level systematics follows Melchin et al. (2011). 2TRD refers to two-thecae repeat distance (Howe, 1983). We introduce a new morphological term "pseudolip" to describe the lip-like, looping list structure underlying the apertural lip, attached to the lateral thecal apertural lists, which has been observed in our specimens of Pseudoretiolities cf. tianbaensis (Fig. 7.5, 7.7). The structure has an open space between it and the true apertural lip.

\section{Superfamily Retiolitoidea Lapworth, 1873}

Definition.-The most recent common ancestor of Metabolograptus ojsuensis and Retiolites geinitzianus and all of its descendants (Node 3, figs. 2 and 3 in Melchin et al., 2011).

\footnotetext{
Figure 8. Scanning electron microscopy images of Pseudoretiolites perlatus Nicholson, 1868: (1, 2) GSC137613, (1) beautifully preserved specimen with seven pairs of thecae, no visible sicula, (2) enlargement of two thecae showing zigzag thecal floor, part of thecal mid-ventral list (a), pleural list (b), and lateral apertural rod (c). Note zigzag distal part of thecal mid-ventral list, section MCM2-98, 59.1-59.2 m, L. convolutus Zone; (3) GSC137614, ancora umbrella with four spiral whorls, prosicula with fine longitudinal rods, and partial preservation of the metasicula (arrow), which is more complete than usual for this species, section DIS92-11, 17.5-18.0 m, L. convolutus Zone; (4) GSC78426, fairly mature specimen with at least six pairs of thecae, well-preserved prosicula, at least one stoma, ML64, upper, L. convolutus Zone, re-illustrated from Lenz and Melchin (1987a); (5, 8) GSC137615, specimen with two pairs of thecae, well-developed ancora umbrella with four spiral whorls, well-preserved prosicula, (5) oblique proximal view, (8) stereopair of profile view, section MRC02, L. convolutus Zone; (6) GSC 137616, stereopair of immature specimen, showing well-developed ancora umbrella with four complete spiral whorls, without preserved sicula, section MCM2-98, 59.1-59.2 m, L. convolutus Zone; (7) GSC 137617, stereopair of immature specimen with well developed ancora umbrella with five spiral whorls, base of theca ${ }^{1}$ mid-ventral list beginning within ancora umbrella (arrow), section MCM2-98, 54.1-59.2, L. convolutus Zone.
} 


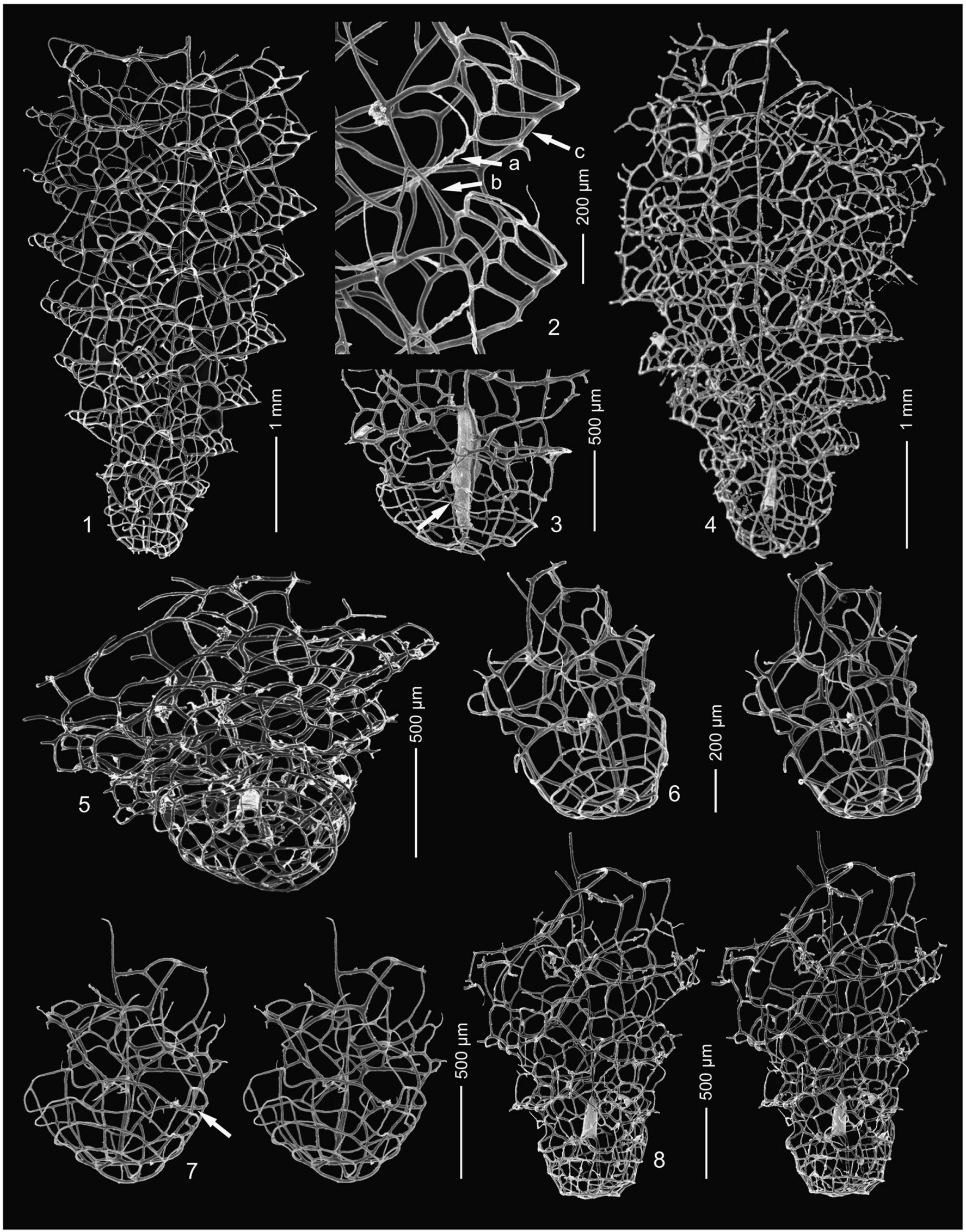


Remarks.-See Melchin et al. (2011) for a full discussion of this taxon and the family Retiolitidae and subfamily Retiolitinae, and their phylogenetic relationships, as well as descriptions of the characteristic synapomorphies of each of these taxa.

Maletz (2014, fig. 17) appears to have accepted the phylogeny proposed by Melchin et al. (2011) but not the classification that Melchin et al. derived from their phylogeny. Instead, Maletz stated that he prefers restricting both the superfamily Retiolitoidea and the family Retiolitidae to those taxa traditionally regarded as "retiolitids", but did not provide any explanation or evidence that this preferred classification (Maletz 2014, fig. 17B) better reflects the phylogeny of these groups of Silurian biserial graptolites. In addition, he noted that the solution is preliminary and "might have to be revised in the light of the interpretation of characteristic homologous features in some Petalolithinae.” Melchin et al. (2011), however, had already taken into account the homologous features shared by some petalolithines and retiolitines and it was partly on this basis that the Retiolitidea was expanded to include the petalolithines. The results in Melchin et al. (2011) suggest that, aside from the stem-family Normalograptidae, all Silurian graptolites belong to two major sister clades, which they named the Monograptoidea and the Retiolitoidea. We believe that this essential aspect of the phylogeny of Silurian graptolites should be reflected in the taxonomy and that the sister clade to the Monograptoidea should have a formal taxon name, which is not the case in the classification of Maletz (2014). As noted by Melchin et al. (2011), the rules of nomenclatural priority require that the sister superfamily to the Monograptoidea be named Retiolitoidea, despite the fact that it includes taxa that are not traditionally regarded as "retiolitids" (just as the Monograptoidea contains some biserial and uni-biserial species). Therefore, as noted above we follow the family-level classification proposed by Melchin et al. (2011).

Family Retiolitidae Lapworth, 1873

Definition.-The first species that acquired a unistipular biserial tubarium in the clade that contains Paramplexograptus madernii and Retiolites geinitzianus and all of its descendants (Node 3, figs. 2 and 3 in Melchin et al., 2011).

Remarks.-This definition is slightly amended from that of Melchin et al. (2011) in that in the original definition the word "aseptate" was included in parentheses after the word "unistipular." This has been omitted here to clarify the point that "aseptate" and "unistipular" are not directly synonymous. Some of the Silurian biserial taxa included in this clade by Melchin et al. (2011) possess a narrow partial median septum on the obverse side, but the pattern of thecal development still indicates that there was no dicalyic and there was only a single stipe of alternately budding thecae. The earliest known member of this clade, Paramplexograptus madernii, is both unistipular and aseptate (Melchin et al., 2011), as are all known members of the Retiolitinae.

\section{Subfamily Retiolitinae Lapworth, 1873}

Definition.- The first ancora-bearing graptolite species within the clade that includes Retiolites geinitzianus that acquired thecae constructed of a full framework of lists and reduced or absent fusellar walls, and all of its descendants (Melchin et al., 2011).

\section{Genus Pseudoretiolites Bouček and Münch, 1944}

Type species.—Retiolities perlatus Nicholson, 1868, by original designation.

Diagnosis (emended from Bouček and Münch, 1944)._-Ancora umbrella deep, with up to five whorls of spiral lists; prosicula and part of metasicula commonly preserved. Nema attached to thecal framework by connecting rods. Mid-ventral thecal lists present throughout, connecting distally to zigzag ventral thecal floors. Thecae with straight, outward-inclined ventral walls. Ancora sleeve reticulum composed of well-developed meshwork covering entire lateral walls. Stomata present. List surfaces smooth to weakly striated.

Remarks.-The most characteristic features of species of this genus that are likely to be recognizable in well-preserved flattened specimens are the deep, spiral ancora and the zigzag lists of the apertural regions of the thecal ventral walls. All of the species of this genus known from isolated specimens possess stomata, although since the stomata do not possess well-developed rims, they cannot normally be seen in flattened material. Thus, stomata have not been described in specimens of Pseudoretiolites rete Richter, 1853, or Pseudoretiolites dentatus Bouček and Münch, 1944, but their otherwise very close similarity to $P$. decurtatus and $P$. perlatus suggests that they are likely to possess stomata as well. Pseudoretiolites rete and $P$. dentatus have never been recognized outside of Germany or the Prague Basin region, due either to poor preservation of the type material (potentially rendering the taxa unrecognizable elsewhere) or, possibly, biogeographical restrictions.

\section{Pseudoretiolites perlatus (Nicholson, 1868) Figure 8.1-8.8}

1868 Retiolites perlatus Nicholson, p. 530, pl. 19, figs. 21, 22.

1908 Retiolites (Gladiolites) perlatus; Elles and Wood, p. 338, pl. 34, figs. 10a-e (f?), text: figs. 221a-c.

Figure 9. Scanning electron microscopy images of Pseudoretiolites decurtatus Bouček and Münch, 1944 and Pseudoretiolites decurtatus Bouček and Münch, 1944?. (1, 2, 4, 5, 7, 8) Pseudoretiolites decurtatus Bouček and Münch, 1944: (1) GSC137619, mature specimen lacking proximal-most portion, note distal tapering of tubarium, unknown location on Cornwallis Island, L. convolutus Zone?; (2) GSC 137620, stereopair of nearly complete specimen with eight pairs of thecae, note thickened, spiralled cortical(?) tissue covering nema, section MRC02, R. orbitus Subzone or L. convolutus Zone; (4) GSC137625, immature specimen, enlargement of thecal floor retaining some fusellar bandaging, section ML64-85-2, $R$. orbitus Subzone; (5) GSC137618, stereopair of immature specimen, showing completely preserved prosicula with fine longitudinal rods, unknown location on Cornwallis Island, ?L. convolutus Zone; (7) GSC137622, stereopair of large specimen with nine pairs of thecae and four stomata, section MRC02, L. convolutus Zone; (8) GSC137623, stereopair of ventro-lateral view of specimen, with seven thecal pairs, at least one collar-like stomatal rim and well-developed prosicula, section ML64-85 \#2, R. orbitus Subzone. (3, 6) Pseudoretiolites decurtatus Bouček and Münch, 1944?, 3, GSC85761, incomplete specimen with nine thecal pairs, prosicula preserved, but ancora umbrella missing, (3) whole specimen, (6) enlargement of sicula showing complete prosicula and some metasicular fusellae, section ML64-85-2, upper $R$. orbitus Subzone. 


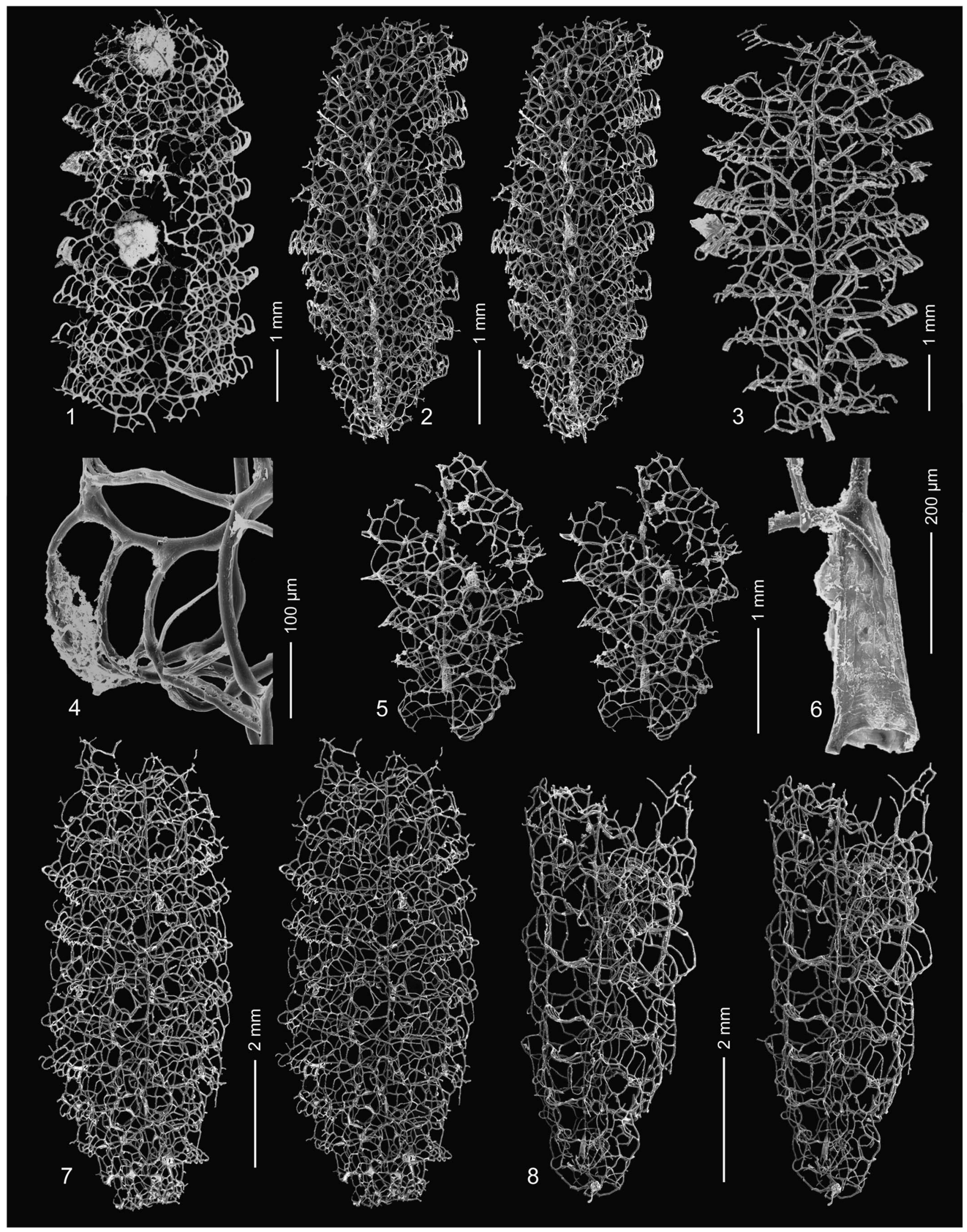


1944 Retiolites (Pseudoretiolites) perlatus; Bouček and Münch, p. 24, pl. 1, figs. 4-7; text: figs. 8a-e, 9c-e.

1968 Pseudoretiolites perlatus; Obut and Sobolevskaya, p. 74, pl. 7, figs. 6-9.

1984 Pseudoretiolites daironi (Lapworth); Chen, p. 49, pl. 6, figs. 9, 12, pl. 7, figs. 1, 3-6.

1987a Pseudoretiolites cf. decurtatus Bouček and Münch; Lenz and Melchin, pl. 1, figs. 2, 3(?), 4-8.

1990 Pseudoretiolites daironi (Lapworth); Ge, p. 79, pl. 8, fig. 20, pl. 9, figs. 4, 5 .

1992 Pseudoretiolites cf. decurtatus Bouček and Münch; Bates and Kirk, p. 120, pls. 7-11, figs. 120-164.

1993 Pseudoretiolites perlatus; Loydell, p. 61, text: fig. 13, fig. 3 (see for an expanded synonymy list up to 1993).

1998 Pseudoretiolites perlatus; Štorch, p. 225, pl. 6, fig. 1, text: fig. 6, fig. 8. [? pl. 6, figs. 7, 9].

Materials.-12 specimens are assigned to this species, all but two of which are immature.

Occurrence.-L. convolutus Zone of Rookery Creek, Cape Manning, an unknown locality, Cornwallis Island, and Dundas Island. Four specimens are identified as $P$. cf. perlatus from L. convolutus Zone, Rookery Creek. Found in the middle to upper $C$. curtus Zone in northern Siberia, and the D. simulans and $P$. leptotheca zones of Czech Republic, and, more commonly, the L. convolutus Zone of Arctic Canada, Great Britain, Czech Republic, Germany, and south China.

Description.-Tubarium up to at least $6.4 \mathrm{~mm}$ long, proximal portion more-or-less triangular in profile, widening steadily from 1.2 to $1.4 \mathrm{~mm}$ across first thecal pair and to $3.0-3.1 \mathrm{~mm}$ across fifth thecal pair, which is the maximum width observed in our specimens. 2TRD $1.0 \mathrm{~mm}$ at the first thecal pair, to an observed maximum of $1.5 \mathrm{~mm}$. Prosicula commonly preserved, $0.3-0.37 \mathrm{~mm}$ long, with longitudinal rods. Virgella $0.5 \mathrm{~mm}$ long, sometimes with preserved fringes of metasicular fusellar tissue. Ancora umbrella deep, reaching the level of the aperture of the prosicula or higher, four to five whorls of spiral lists, $0.8-1.1 \mathrm{~mm}$ diameter. Small, ventral orifices occur between ancora umbrella and first thecal pair. Medium-sized, rounded orifices may be present on both lateral walls above the ancora. Thecae with straight, outward-inclined ventral walls. Ventral walls of thecae consist of a mid-ventral list and three to five paired zigzag lists, inclined $\sim 80^{\circ}$ to nema for first two thecal pairs, and $50^{\circ}-60^{\circ}$ distally. Mid-ventral list of theca $1^{1}$ originates from within the inside surface of the ancora umbrella. Pleural lists present, inclined inward. Ancora sleeve reticulum a coarse meshwork throughout, with mesh sizes generally ranging from $0.25-0.45 \mathrm{~mm}$, made of five- to six-sided polygons. Stomata present, rounded, more-or-less equidimensional, $\sim 0.4-0.6 \mathrm{~mm}$ across, not elevated above reticulum.

Remarks.-Although there are no fully mature specimens in the collection, the moderately rapid widening of the tubarium for at least the first six thecae, the moderate angle of thecal ventral walls to the nema, and the thecal spacing match well with the material described by Elles and Wood (1908, pl. 34, figs. 10a-f). The type specimen, illustrated by Nicholson, 1868, and reillustrated by Elles and Wood (1908, pl. 34, fig. 10a), is without the proximal end. In comparison with the very well-preserved material described from the Czech Republic (Štorch, 1998), the Arctic specimens are in general agreement, differing in being slightly narrower at the level of the fifth thecal pair, and possessing a slightly closer thecal spacing. The material described from Wales by Loydell (1993) is fragmentary, but the distal specimens match well with those of this species described from the Czech Republic. In comparison with Chinese material (Chen, 1984; Ge, 1990), both the Arctic and Czech specimens differ in having fewer zigzag lists in the thecal ventral wall, and in widening much more rapidly, but are otherwise very similar.

The details of the morphology of this taxon were documented by Bates and Kirk (1992, specimens identified as Pseudoretiolites cf. decurtatus), who clearly illustrated the details of the thecal framework, the traces of metasicular tissue preserved on the virgella (e.g., their figs. 122, 126, 128, 129), and the very finely striated list surfaces (see also Lenz and Melchin, 1987a). A number of authors have also shown that mature specimens commonly have continuous membranes preserved on the thecal walls (e.g., Elles and Wood, 1908; Bouček and Münch, 1944).

Pseudoretiolites decurtatus Bouček and Münch, 1944 Figure 9.1, 9.2, 9.4, 9.5, 9.7, 9.8

1944 Retiolites (Pseudoretiolites) decurtatus Bouček and Münch, p. 30, text-figs. 3a-c, 9a.

1952 Pseudoretiolites decurtatus; Münch, p. 74, pl. 12, fig. 5.

1982 Retiolites decurtatus; Lenz, p. 32, fig. 15F.

1987b Pseudoretiolites cf. decurtatus; Lenz and Melchin, fig. 3, figs. A-G.

1984 Pseudoretiolites decurtatus; Chen, p. 50, pl. 7, figs. 4, 7.

?1998 Pseudoretiolites perlatus (Nicholson); Štorch, p. 225, pl. 6, figs. 7, 9 [non fig. 1, text-fig. 6, fig. 8].

Figure 10. Scanning electron microscopy images of Pseudoretiolites hyrichus n. sp.: (1, 3) paratype GSC137632, (1) enlargement showing deep ancora umbrella and partially preserved metasicula, showing longitudinal rods on prosicula (a), and base of median ventral list of th $1^{1}$ attached to inner surface of ancora umbrella (b), (3) stereopair of specimen with two thecal pairs, complete ancora umbrella with five spiral whorls, and paired lateral orifices; prosicula and most of metasicula preserved, section MCM96-9, 1.8-1.9 m, L. convolutus Zone; (2) paratype GSC137633, immature specimen, proximal view of ancora umbrella with six spiral whorls, and partially preserved metasicula, section MCM96-9, 1.8-1.9 m above, L. convolutus Zone; (4) paratype GSC137634, stereopair of distal part of tubarium with three thecal pairs, section MCM96-9, 1.8-1.9 m, L. convolutus Zone; (5, 6) holotype GSC137635, (5) stereopair, immature specimen with very well preserved ancora umbrella with four spiral whorls, two thecal pairs, large paired lateral orifices, and prosicula and most of metasicula preserved, showing attachment of nema to connecting rods (a), pleural list (b), and mid-ventral list (c), (6) enlargement of part or proximal end showing smooth list surfaces and partially preserved metasicular fusellae, section MCM96-9, 1.8-1.9 m above reference, L. convolutus Zone. 

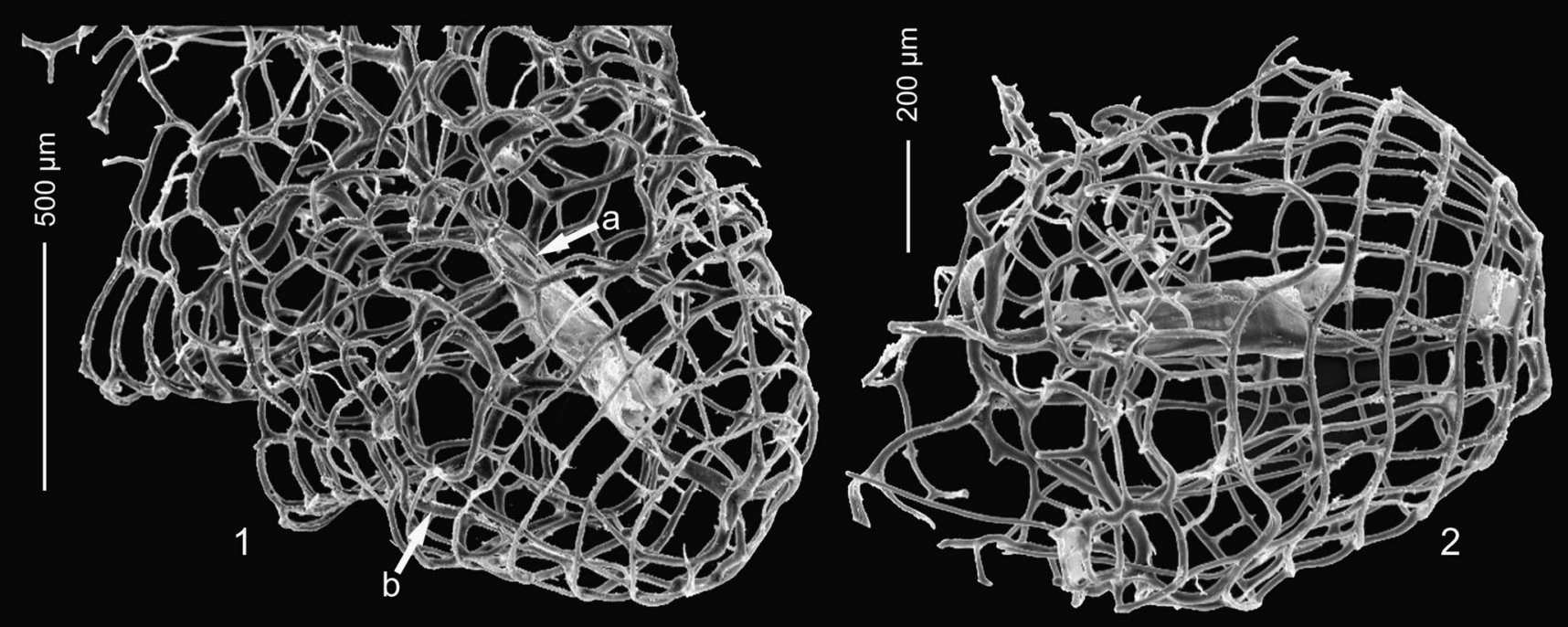

bes s.t. C.1 1 .

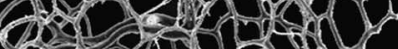

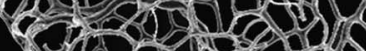

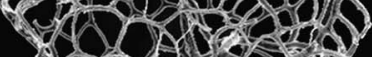
1001.23 -201 Jian gene 121 was $1 \mathrm{k}$. 53010

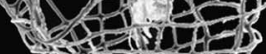
(1) Lavie

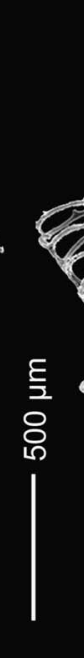

120

Sold win 120 on $k$ on 200 1040 in 2010 10 in (a) 109 (2) 100 in

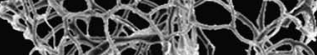
viou 4 i 2. A Nuy 6.) 5 (1) 1. 010 interty bos

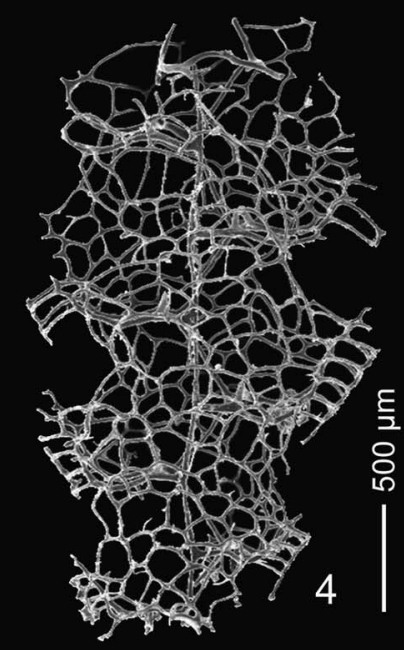

tast (2) 100 ato 100 2. 14025 1012 ans 3020005 $3 \times 15020$

12010 Q 70.50 10010 E +20.104. $x=0,0$ ginders now 320 ? if
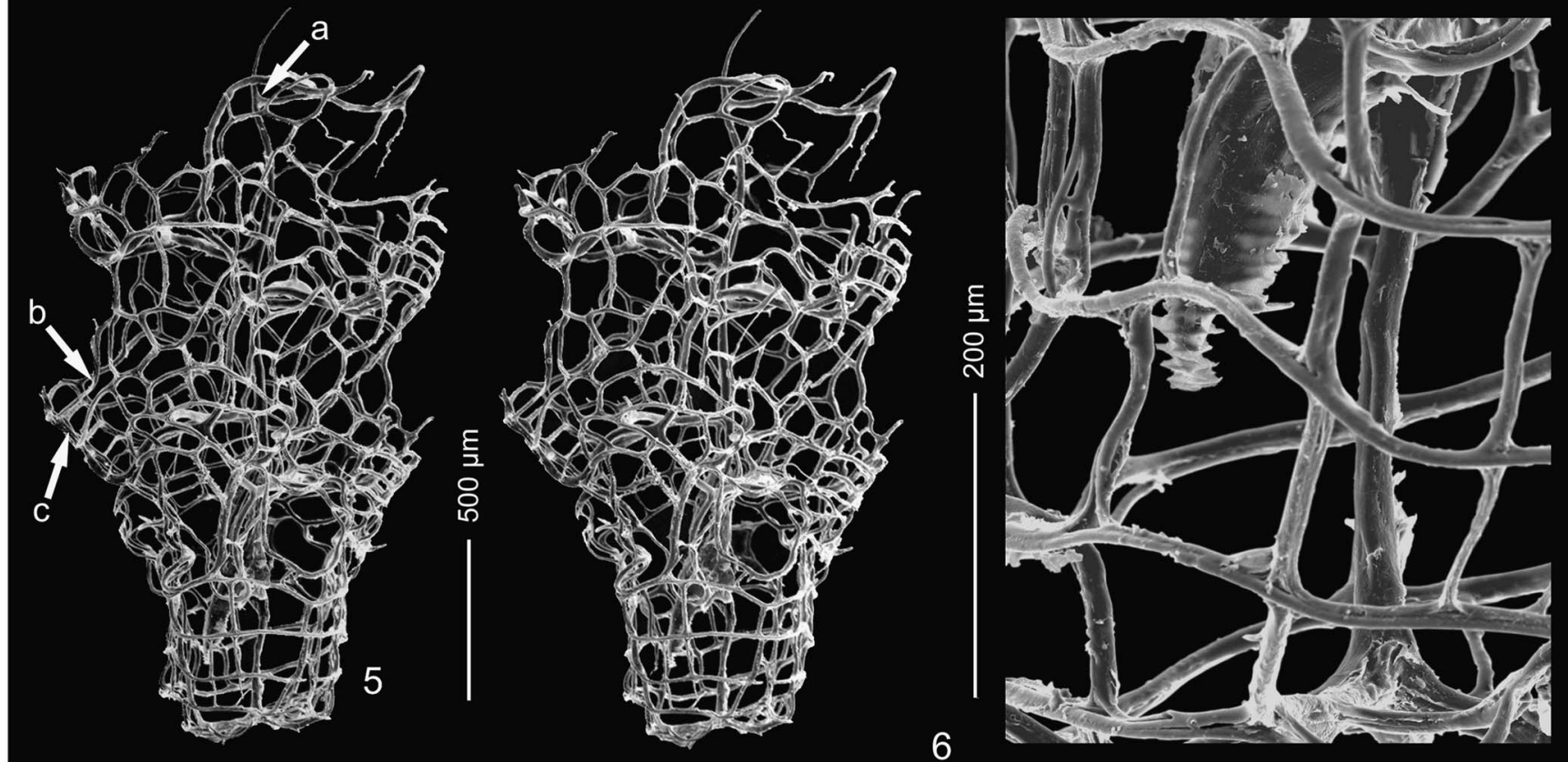
Materials.-10 specimens, at least six mature, but only a very few with a preserved ancora umbrella, plus three questionably assigned to this species.

Occurrence.- $R$. orbitus Subzone and L. convolutus Zone; Cape Manning, Rookery Creek, and an unknown locality, Cornwallis Island. 10 specimens identified as $P$. cf. decurtatus from Cape Manning and Rookery Creek. Found in the R. orbitus Subzone and L. convolutus Zone, and S. guerichi and $S$. turriculatus zones (lower Telychian) in Arctic Canada, Czech Republic, Germany, and south China.

Description.-Tubarium up to $9 \mathrm{~mm}$ long, ovate in outline, widening at moderate rate to the level of fifth or sixth thecal pair, then distally decreasing in width. Width at first thecal pair $1.0-1.3 \mathrm{~mm}$, maximum width $2.8-4.0 \mathrm{~mm}$, but tapering somewhat distally. 2TRD is $1.0-1.2$ at the first thecal pair, $1.5-1.7$ distally. Prosicula generally preserved, $0.35-0.5 \mathrm{~mm}$ long, with longitudinal rods, some metasicular fusellae preserved. Virgella $0.5 \mathrm{~mm}$ long. Ancora umbrella rarely preserved, $0.8-1.0 \mathrm{~mm}$ diameter and moderately deep (approximately to level of prosicular aperture, see Fig. 9.5), with three to four whorls of spiral lists. Ventral walls of thecae are marked by a mid-ventral list and six to seven pairs of relatively fine, zigzag lists near the aperture. Thecae with straight ventral walls inclined at $70-75^{\circ}$ to axis of tubarium distally. Pleural lists present, inclined inward. Reticulum meshes of relatively delicate lists forming moderately fine meshwork, meshes five- to six-sided, ranging from $0.1-0.3 \mathrm{~mm}$ diameter. Ancora sleeve seams all facing outwards. Stomata round to ovate, $0.3-0.6 \mathrm{~mm}$, bounded by slightly elevated, delicate, collar-like structure; spacing varies somewhat on individual tubaria from 0.3 to $0.6 \mathrm{~mm}$.

Remarks.-Specimens of this species largely overlap in dimensions of width and thecal spacing with those of Pseudoretiolites perlatus. Pseudoretiolites decurtatus is distinguished from $P$. perlatus in having a finer reticulum on the ancora sleeve, as documented by Bouček and Münch (1944), as well as more strongly inclined thecae mesially and distally, and, in our specimens, in having more pairs of zigzag list near the thecal apertures. The specimens illustrated by Lenz and Melchin (1987b, fig. 3C, F, G), one of which is reillustrated herein (Fig. 9.3, 9.6), were initially identified as $P$. cf. decurtatus. These specimens differ from typical specimens of Pseudoretiolites decurtatus only in possessing a coarser reticulum on the ancora sleeve, and are here questionably identified as Pseudoretiolites decurtatus. These specimens also show traces of preservation of continuous membranes on the thecal walls, which were also documented in the type material of $P$. decurtatus by Bouček and Münch (1944).

\section{Pseudoretiolites cf. tianbaensis (Ge, 1990)}

Figure 7.1-7.8

cf. 1990 Arachniograptus? tianbaensis Ge, p. 80, pl. 8, figs. 10, 19 pl. 10, figs. $2-4$.

Materials. -17 specimens, three of which are mature, and one immature specimen preserved up to the level of the second thecal pair.

Occurrence.-L. convolutus, S. guerichi and S. turriculatus zones from Cape Manning and Snowblind Creek, Cornwallis Island, and Cape Sir John Franklin, Devon Island. Pseudoretiolities tianbaensis is found in the L. convolutus Zone of south China.

Description.-Tubarium triangular, widening continually and uniformly from ancora umbrella up to at least the eighth thecal pair (the longest specimens in collection). Widens from $\sim 1.0 \mathrm{~mm}$ across ancora umbrella to $2.5-3.0 \mathrm{~mm}$ distally (extrapolated to $2.8-3.4 \mathrm{~mm}$ when flattened). $2 \mathrm{TRD}$ is $1.8-1.9 \mathrm{~mm}$ (10.5-10 in $10 \mathrm{~mm}$ ). Sicula not preserved. Ancora umbrella moderately deep, three to four whorls of spiral lists, merges smoothly with first thecal pair and ancora sleeve, without lateral orifices, but with small ventral orifices. Thecae with straight ventral walls, inclined $\sim 45^{\circ}$ to tubarium axis, distal ends of thecal floors with four to five pairs of zigzag lists that often retain fusellar tissue. Underlying the thecal floor is a relatively robust and ventrally curved external 'pseudolip' (defined above; see Fig. 7.5, 7.7) that creates an orifice between it and the overlying thecal lip, resulting in the appearance of double thecal apertural lips. Internally, most of the thecal framework is missing, preserving only some mid-ventral lists and transverse rods. Entire lateral surfaces of tubarium with a robust meshwork reticulum made of polygonal, sturdy meshes that are of uniform size at any one level, but which slowly increase in size distally. Stomata ovate, spaced at $\sim 1 \mathrm{~mm}$ intervals, with slightly raised rims, $\sim 0.58 \mathrm{~mm}$ long and $0.38 \mathrm{~mm}$ wide.

Remarks.-Specimens of this species differ from any of the associated Arctic species of Pseudoretiolites in several ways: a robust and relatively evenly distributed reticular meshwork; the smooth junction of the ancora umbrella and succeeding

Figure 11. Scanning electron microscopy images of Pseudoretiolites? sp.: (1) GSC137637, specimen showing complete prosicula and metasicula, base of broken mid-ventral list (arrow) section MCM96-9 1.6-1.7 below reference, $R$. orbitus Subzone; (2, 6) GSC137638, (2) broken prosicula with fine longitudinal rods, complete metasicula and proximal portion of theca $1^{1}$, outside of which is remnant of ancora umbrella with five spiral whorls, (6) enlargement showing proximal part theca 1 and porus (arrow), section MCM88-8 11.5, upper D. triangulatus/D. pectinatus Subzone or lower R. orbitus Subzone; (3) GSC137639, stereopair of partial specimen with complete sicula, partial preservation of base of theca 1 and broken mid-ventral list of theca 1 (arrow), MCM96-9 1.6-1.7 below reference, $R$. orbitus Subzone; (4) GSC137640, enlargement showing distal part of metasicula with proximal part of theca $1^{1}$ aperture, section MCM88-8 11.5, upper D. triangulatus/D. pectinatus Subzone or lower R. orbitus Subzone; (5) GSC137641, well preserved ancora umbrella with six spiral whorls, prosicula preserved, section section MCM88-8 11.5, upper D. triangulatus/D. pectinatus Subzone or lower R. orbitus Subzone; (7) GSC137642, stereopair with complete ancora umbrella and post-umbrella meshwork up to the level of about theca $1^{1}$, complete sicula, base of mid-ventral list (a) and attachment of nema to connecting rod (b), MCM96-9 1.6-1.7 below reference, R. orbitus Subzone; (8) GSC137643, poorly preserved specimen with coarse and very irregular meshwork, only partially preserved ancora umbrella, and complete prosicula and metasicula, section MCM88-8 11.5, upper D. triangulatus/D. pectinatus Subzone or lower R. orbitus Subzone; (9, 10) GSC137644, (9) laterally flattened specimen showing zigzag thecal walls with preserved fusellar bandaging, and thickened mid-ventral list of distal-most preserved theca (arrow), (10) enlargement showing zigzag thecal ventral floors, lateral apertural rod (arrow), underlain by heavy cortical tissue, section MCM88-8 11.5, upper D. triangulatus/D. pectinatus Subzone or lower R. orbitus Subzone. 


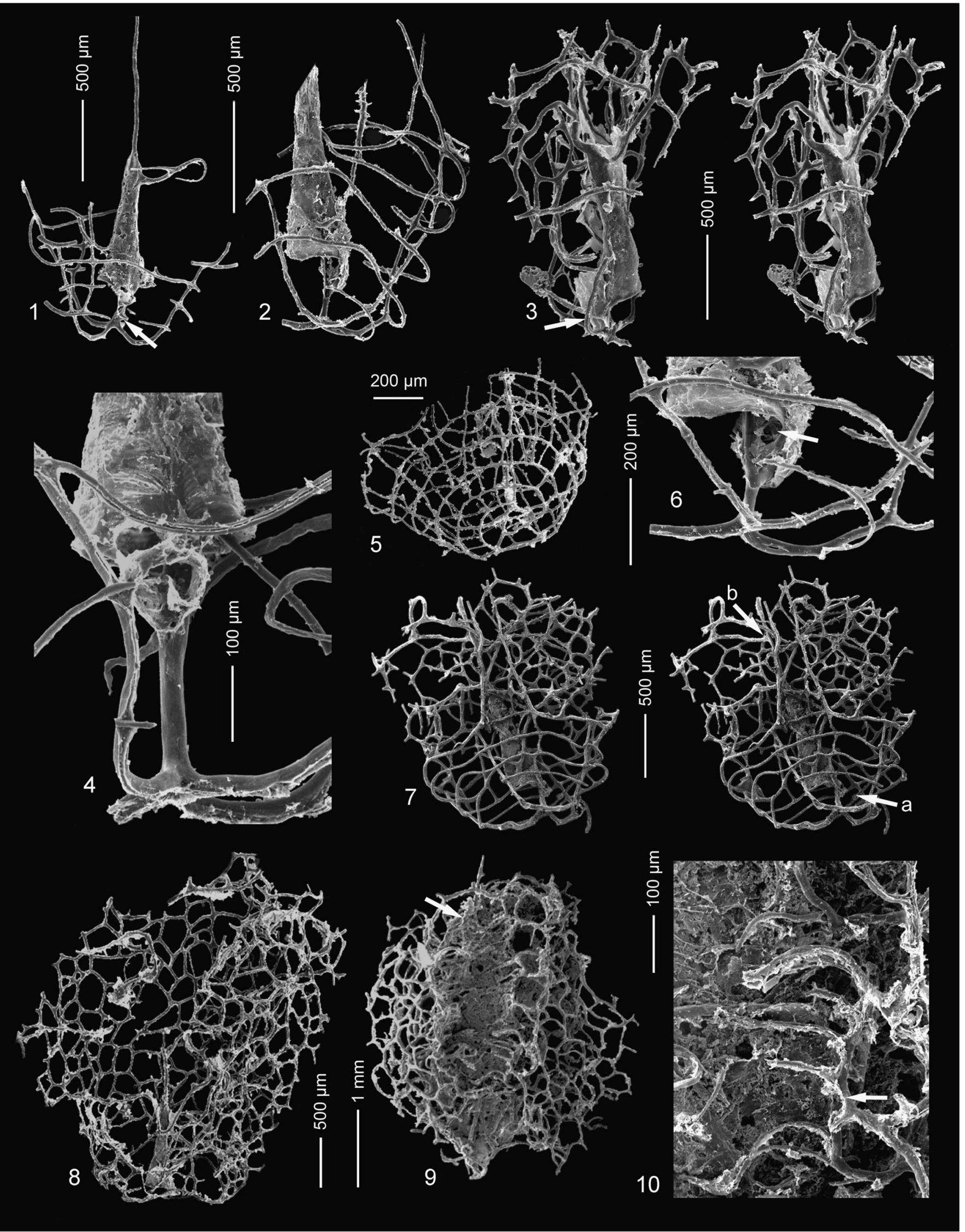


remainder of the tubarium; and the occurrence of the robust, ventrally projecting 'pseudolip'. Comparison with the Chinese specimens of Pseudoretiolites tianbaensis is somewhat difficult because they are flattened and only moderately well preserved. However, two observations give support to the possible affinities of the Arctic material with that species. These are the smooth merging of the rather round ancora umbrella with the remainder of the tubarium, and the possession of a reticulum of small reticular meshes of near-uniform size (this feature is well shown in Ge, 1990, pl. 10, fig. 4), although there is no hint of the unique 'pseudolip' in Ge's illustrations. Thecal spacing and maximum tubarium width of the Chinese and Arctic specimens are very similar.

\section{Pseudoretiolites hyrichus new species}

Figure 10.1-10.6

\section{Holotype.-Holotype GSC137635, Paratype specimens GSC137632-137634, 137636.}

Diagnosis.-Ancora umbrella deep with four to five whorls of spiral lists. Two large rounded lateral orifices on obverse and reverse walls, ventral orifices small. Thecal zigzag floors long, inclined $\sim 30^{\circ}$ to nema, overlapping minimally. Thecae with straight, moderately inclined ventral walls. Reticulum a moderately dense meshwork made of polygons that vary in size. Sicula preserves complete prosicula and most of metasicula.

Materials.-11 specimens, all immature, except for two specimens without the ancora umbrella.

Occurrence.- $-R$. orbitus Zone and L. convolutus Zone, Cape Manning, Cornwallis Island.

Description.-Tubarium narrow. Width across first thecal pair $1.2-1.3 \mathrm{~mm}$, maximum width (one specimen) $1.65 \mathrm{~mm}$. 2TRD $\sim 1.5 \mathrm{~mm}$ ( $\sim 13.3$ in $10 \mathrm{~mm}$ ) (single specimen). Sicula comprises complete prosicula and most of metasicula, the latter generally having only approximately one-half of fusellar wall preserved. Sicula $0.7-0.8 \mathrm{~mm}$ long, prosicula $\sim 0.45 \mathrm{~mm}$. Prosicula possesses longitudinal rods. Ancora umbrella U-shaped or broadly $\mathrm{V}$-shaped, almost as deep as wide, 0.6-1.0 mm wide, composed of four to five whorls of spiral lists, enclosing the aperture of the prosicula (Fig. 10.1). Paired large, rounded to broadly ovate lateral orifices on both obverse and reverse walls; small ventral orifices below first thecae. Thecae with straight ventral walls, distal part composed of a mid-ventral list and five pairs of zigzag lists, inclined $\sim 30^{\circ}$ to nema, overlapping only to a small degree. Mid-ventral list of theca $1^{1}$ originates within the inside surface of the ancora umbrella. Pleural lists present, inclined inward. Ancora sleeve meshwork moderately coarse, meshes irregular in size; stomata present, somewhat rounded, rims level with reticular meshwork. List surfaces smooth to very finely striated.

Etymology.-hyrichus: Gr., basket; referring to deep ancora umbrella.

Remarks.-Specimens of this species, although being predominantly preserved in juvenile stages, are distinctive among species of this genus in a number of ways: relatively narrower width; its ancora umbrella is deep and V- to U-shaped; and large, paired lateral orifices are present on obverse and reverse sides. The thecae are inclined at a low angle, and its sicula is more completely preserved than the other species of this genus described above. There is no evidence of preservation of continuous fusellar thecal membranes.

\section{Pseudoretiolites? sp. \\ Figure 11.1-11.10}

Materials._-34 poorly preserved specimens, all fragmentary, predominantly of sicula and ancora umbrella; most distal fragments partially or fully flattened.

Occurrence.-D. triangulatus/D. pectinatus Subzone to $R$. orbitus Subzone and possibly lower L. convolutus Zone, from Cape Manning, Cornwallis Island, and Dundas Island.

Description.-Tubarium widening rapidly, width at first thecal pair $2-2.5 \mathrm{~mm}$, distal width at least $3.7 \mathrm{~mm}$ in dorsoventerally compressed specimen. 2TRD cannot be reliably measured. Prosicula and metasicula complete, total length $\sim 1.05 \mathrm{~mm}$, prosicular length $\sim 0.3 \mathrm{~mm}$. Prosicula possesses longitudinal rods. Theca $1^{1}$ mid-ventral list appears to arise from metasicula. Proximal portion of theca $1^{1}$ is preserved, revealing visible porus near metasicular rim (Fig. 11.2, 11.6). Ancora umbrella deep, bowl-shaped, with five to six whorls of spiral lists, $1.3 \mathrm{~mm}$ wide. Distal portion of mid-ventral list attached to numerous zigzag lists defining the distal thecal floor, some with completely preserved fusellum (Fig. 11.9, 11.10). Ancora sleeve reticulum of moderately coarse polygonal meshes of various sizes. List surfaces smooth to very finely striated.

Figure 12. Scanning electron microscopy images of Rotaretiolites exutus, Bates and Kirk, 1992, Rotaretiolites cf. exutus Bates and Kirk, 1992, Pseudoplegmatograptus obesus (Lapworth 1877) and Pseudoplegmatograptus? sp.. (1, 2, 5, 7) Rotaretiolites cf. exutus Bates and Kirk, 1992: (1, 5) GSC137661, (1) stereopair of distal part of tubarium, arrows point to spines on lateral margins of thecal apertures (a), and mid-ventral list of thecae (b), (5) enlargement of list showing very coarse parallel striae, section LL1-77, guerichi Zone?; (2) GSC137662, specimen with basal pair of thecae, arrows point to spines on lateral margin of thecal aperture (a), and mid-ventral list (b), and also to prosicular ring (c), section MSC07, 3 m above 01G, S. guerichi Zone?; (7) GSC137663, proximal fragment with one thecal pair and prosicular ring; arrows point to spines on lateral margins of thecal apertures (a), and mid-ventral lists (b), and prosicular ring (c), section LL1-77, S. guerichi Zone?. (3, 4) Pseudoplegmatograptus obesus (Lapworth 1877): (3) GSC78423, distal portion of tubarium with paired apertural spines and two stomata, missing the ancora umbrella, arrow indicates partly preserved mid-ventral list on distal theca, section LL1-77, S. guerichi Zone?; (4) GSC137664, immature specimen with shallow ancora umbrella, and two thecal pairs with long paired spines emerging from apertural rims, arrows indicate pleural list (a), lateral apertural rod (b), and partly preserved prosicula (c), section MSC07, 3 m above 01G-1, S. guerichi Zone?. (6) Rotaretiolites exutus Bates and Kirk, 1992, GSC114225; proximal end with very simple ancora umbrella, prosicular ring and one thecal pair; note absence of spines. $(8,9)$ Pseudoplegmatograptus? sp.: GSC137665, (8) stereopair of distal part of tubarium with well-developed paired thecal spines and three stomata, (9) stereopair enlargement of portion of tubarium to show zigzag thecal floors, long paired spines and three stomata, unknown location on Cornwallis Island, ?L. convolutus Zone. 


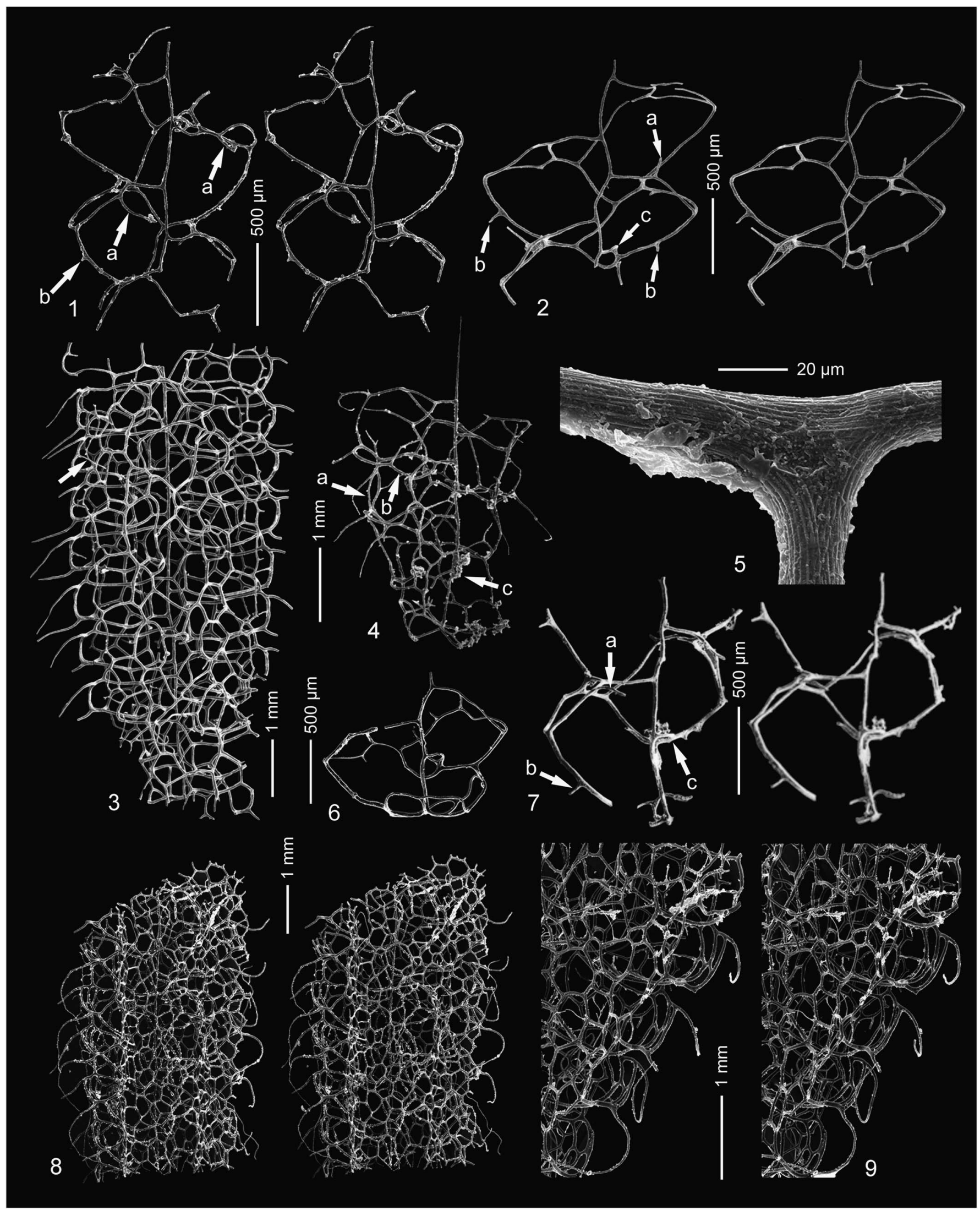


Remarks.-This is the biostratigraphically lowest retiolitine species in Arctic Canada (as well as globally), and is considered the most primitive (see Phylogenetic analysis herein). Owing to the poor preservation, resulting in lack of detail on thecal form, internal structure, evidence of stomata, it is not possible to assign this species confidently to Pseudoretiolites, although the zigzag distal thecal floors and proximal structure suggest affinities with those species. This appears to be a new species, but material is not complete enough for full description of a new taxon.

An unusual attribute of these specimens is that the prosicula and metasicula are both completely preserved. Some specimens exhibit fusellar remnants of the base of theca $1^{1}$ (Fig. 11.3, 11.4) as well. In this respect, this taxon appears to be primitive in relation to the condition in all other known species of Pseudoretiolites, in which the prosicula is commonly preserved but the metasicula, if represented at all, is normally incomplete. Later retiolitines normally preserve only the prosicula or just the virga (e.g., Bates et al., 2005).

\section{Genus Pseudoplegmatograptus Příbyl, 1948}

Type species.-Retiolites perlatus obesus Lapworth 1877, p. 137 , by original designation.

Diagnosis (emended from Př́byl, 1948)._-Ancora umbrella shallow, saucer-shaped, with coarse, hexagonal-pentagonal meshes. Prosicula present. Nema attached to connecting rods throughout. Thecal mid-ventral lists present only in more distal thecae, forming ventral wall of thecae; transverse rods throughout. Thecal framework also includes pleural lists and zigzag thecal framework lists. Thecae with straight, outwardinclined ventral walls. Ancora sleeve may form double layer in mature specimens (see Bates and Kirk, 1992). Thecal lips are horizontal lists to which are connected long, paired spines that may be distally extended by fine, or lace-like bifurcations or multifurcations (see Lenz and Kozłowska, 2007). Stomata present.

Pseudoplegmatograptus obesus (Lapworth, 1877) Figure 12.3, 12.4

1877 Retiolites perlatus obesus Lapworth, p. 137, pl. 6, fig. 29.

1944 Plegmatograptus obesus obesus; Bouček and Münch, p. 6, text-figs. 1a-g, 2a-b, pl. 1, figs. 1, 2.

1952 Pseudoretiolites (Plegmatograptus) obesus; Münch, p. 75, pl. 12, figs.1a-c.

1982 Pseudoplegmatograptus obesus obesus; Lenz, p. 41, figs. 16E, 17A, B.

1984 Pseudoplegmatograptus obesus; Chen, p. 50, pl. 7, figs. 5, 8, pl. 8, figs. 1, 2.

1987a Pseudoplegmatograptus obesus obesus; Lenz and Melchin, pl. 1, fig. 1.

1990 Pseudoplegmatograptus obesus; Ge, p. 80, pl. 9, fig. 3, pl. 10, fig. 6.

1991 Pseudoplegmatograptus obesus; Tomczyk, Urbanek, and Teller, p. 300, pl. 185, fig. 1.

1992 Pseudoplegmatograptus obesus; Bates and Kirk, p. 176, figs. 171-183, 193-250 (non figs. 184-192).
1993 Pseudoplegmatograptus obesus; Loydell, p. 59, text: fig. 13, fig. 24 (see for additional synonymy).

Materials.-One mature and well-preserved specimen without an ancora umbrella, one immature specimen with ancora umbrella and two thecal pairs, and four other fragmentary specimens.

Occurrence.-Snowblind Creek, Cornwallis Island, from S. guerichi Zone. Found in the S. sedgwickii, S. halli, S. guerichi, $S$. turriculatus and $S$. crispus zones (upper Aeronian to mid Telychian) in Arctic Canada and Yukon, Canada, Britain, Czech Republic, Siberia, Germany, Poland, Denmark (Bornholm), and south China.

Remarks. - The single mature specimen lacking the ancora umbrella was previously illustrated by Lenz and Melchin (1987a, pl. 1, fig. 1), but the image is included here for the purpose of demonstrating the complete retiolitine fauna occurring in the Aeronian and lower Telychian of the Canadian Arctic. Unlike the occurrences of Pseudoretiolites, Pseudoplegmatograptus is rare in the Canadian Arctic. Species of Pseudoplegmatograptus are distinguished from those of Pseudoretiolites by a simple, shallow ancora umbrella with hexagonal/pentagonal meshes, paired thecal apertural spines, lack of zigzag thecal ventral floors, and development of mid-ventral lists only in the distal part of the tubarium. P. obesus is characterized by a uniform and moderately dense reticulum as compared with the much greater reticulum density of $P$. reticulatus Bouček and Münch, 1944 (e.g., Hutt, 1974; Lenz et al., 2003).

The morphological details of this species were described by Bates and Kirk (1992). Some of the specimens illustrated as $P$. obesus by Bates and Kirk (1992, figs. 184-192), however, clearly show zigzag ventral thecal floors and no thecal apertural spines, suggesting that these specimens represent a species of Pseudoretiolites rather than Pseudoplegmatograptus.

The morphometrics our specimens of $P$. obesus are as follows: ancora umbrella shallow (see Fig. 12.4), of hexagonal/ pentagonal meshes without spiral lists; maximum tubarium width $\sim 4.0 \mathrm{~mm}$, exclusive of spines; eight pairs of thecae spaced the rate of $\sim 11$ in $10 \mathrm{~mm}$ (=2TRD $1.82 \mathrm{~mm})$; paired thecal aperture spines $\sim 1 \mathrm{~mm}$ long; at least two large, slightly ovate stomata are present; and, ancora sleeve a coarse meshwork. Prosicula and virgella $\sim 1 \mathrm{~mm}$ long. Pleural lists are approximately vertical, and lateral apertural rods almost horizontal. As far as we are aware, no specimens of this species have been reported that show continuous membranes of preserved tissue on the thecal walls.

\section{Pseudoplegmatograptus? sp.}

Figure 12.8, 12.9

Materials.—Two well-preserved distal fragments.

Occurrence.-L. convolutus Zone, Cape Manning and unknown locality, Cornwallis Island. 
Remarks.-This taxon is represented by only two distal specimens, which have an unusual combination of features: zigzag ventral thecal floors as is typical of Pseudoretiolites; but long, paired spines on the margins of the thecal rims, typical of Pseudoplegmatograptus. The absence of information about the ancora umbrella, however, means it cannot assigned with confidence to either genus. Since the specimens possess thecal apertural spines, which our phylogenetic analysis indicates is an apomorphic trait for Pseudoplegmatograptus, we have questionably assigned them to that genus. The reticulum consists of moderately sized polygonal meshes, interrupted by ovate, raised stomata. Tubarium width $4 \mathrm{~mm}$ exclusive of spines; 2 TRD $1.9-1.7 \mathrm{~mm}$ (10.5-11.8 in $10 \mathrm{~mm})$.

\section{Genus Rotaretiolites Bates and Kirk, 1992}

Type species.-Rotaretiolites exutus Bates and Kirk, 1992, p. 56, pls. V-VI, figs. 54-119, 251, 252, by original designation.

Diagnosis (emended from Bates and Kirk, 1992).-_Sicula represented by prosicular apertural ring. Ancora umbrella simple, with four radial ribs terminating in subcircular rim. Reverse zigzag list extends from prosicular ring. Nema attached to connecting rods. Thecae consist of everted apertural loops, dorsal transverse rods and mid-ventral lists arising from center of transverse rods of previous thecae. Mid-ventral lists inclined and slightly convex outward. Mid-ventral list of theca $1^{1}$ attached directly to ancora umbrella rim, that of $1^{2}$ attached to zigzag list close to prosicular ring. Ancora umbrella rim joined to mid-ventral list of $1^{2}$ by unseamed list. Ancora sleeve not developed. Bandages linearly and coarsely striated.

\section{Rotaretiolites exutus Bates and Kirk, 1992}

Figure 12.6

[non] Retiolites sensu lato sp. Hutt, Rickards and Skevington, 1970 p. 7, pl. 1, figs. 19, 20.

1992 Rotaretiolites exutus Bates and Kirk, p. 56, pls. V- VI, figs. 54-119, 251, 252.

2001 Rotaretiolites exutus; Kozłowska-Dawidziuk and Lenz, fig. 3.11.

Materials.-A single, well-preserved, proximal end of an immature specimen.

Occurrence.-Snowblind Creek, Cornwallis Island. From S. guerichi or S. turriculatus Zone. This species is thus far known only from southern Sweden and Arctic Canada, and occurs in the lower Telychian (S. guerichi and/or S. turriculatus Zone).

Remarks.-Although the present specimen is immature, it agrees closely with the holotype, the morphology of which was described in detail by Bates and Kirk (1992). Specimens of this species possess a very shallow, saucer-like, wheel-shaped ancora umbrella in which there are four radial lists joined to the virgella. The very simple thecal apertural lists are declined at $35^{\circ}-45^{\circ}$. The mid-ventral list of theca $1^{1}$ is attached directly to the ancora umbrella rim, whereas those of more distal thecae are attached to transverse rods. Pleural lists and lateral apertural rods are absent. A robust prosicular ring marks the apertural region of the prosicula. List micro-morphology is of distinctive, coarse, parallel ridges (see Bates and Kirk, 1990, figs. 72, 73, $112,113,115,117)$, a feature that appears to be unique to specimens of this species and those we have assigned to Rotaretiolites $\mathrm{cf}$. exutus. The Arctic specimen differs from the type only in that the former is somewhat more flattened.

The specimen of "Retiolites sensu lato sp." illustrated in Hutt et al. (1970, pl. 1, figs. 19, 20), considered by Bates and Kirk (1992) to belong to $R$. exutus, is assigned here to Rotaretiolites cf. exutus (see below).

Bates and Kirk (1992) interpreted the ancora of Rotaretiolites exutus to have a spiral mode of construction based on the pattern of fringes of increments in the seams of the ancora lists (see their fig. 81). None of the described specimens of this species, however, show continuous spiral lists in the ancora constructed of cortical bandages, as is seen in species of Pseudoretiolites (e.g., Fig. 8.3) and Aeroretiolites cancellatus (Fig. 14.3).

\section{Rotaretiolites cf. exutus Bates and Kirk, 1992} Figure 12.1, 12.2, 12.5, 12.7

1970 Retiolites sensu lato sp. Hutt et al., p. 7, pl. 1, figs. 19, 20. 2014 Rotaretiolites sp. Maletz, p. 519, fig. 24E.

Materials.-Three moderately well-preserved but incomplete specimens, the longest with two thecal pairs; one specimen with incomplete ancora.

Occurrence.-Snowblind Creek, Cornwallis Island, from S. guerichi Zone.

Description.-Tubarium width 1.2-1.5 mm. 2TRD estimated to be $\sim 1.4 \mathrm{~mm}(\sim 14$ in $10 \mathrm{~mm})$. Length of prosicular interval $0.45 \mathrm{~mm}$, length of metasicular region and virgella $0.5 \mathrm{~mm}$. Prosicular ring present (Fig. 12.2, 12.7). Ancora umbrella only partially preserved in one specimen. Spines less than $1 \mathrm{~mm}$ long present on mid-ventral lists and on lateral thecal rims (Figs. 12.1, 12.2, 12.7). Prominent parallel striae on all lists.

Remarks.-The Arctic specimens are similar in both dimensions and form of the thecal framework to the specimens assigned to Retiolites sensu lato sp. by Hutt et al. (1970) and the specimen of Rotaretiolites sp. illustrated by Maletz (2014, fig. 24E). As with the present material, the specimen illustrated by Hutt et al. (1970, pl. 7, fig. 19) shows well-developed spines on both the mid-ventral lists and lateral apertural margins. The specimen illustrated by Maletz (2014, fig. 24E) also clearly shows spine bases on the mid-ventral lists of the first thecal pair and also has what may be a small, curved spine on the reverse, lateral margin of theca $1^{1}$. We therefore consider that all of these specimens likely to belong to the same species. The specimens of Hutt et al. and Maletz show that this species has a simple, small ancora with four radial lists, and the incomplete ancora seen in our material (Fig. 12.7) is consistent with this. These specimens have most of the diagnostic characteristics of R. exutus, including similar width and thecal spacing, but differ in the presence of the spines on mid-ventral lists and on lateral 


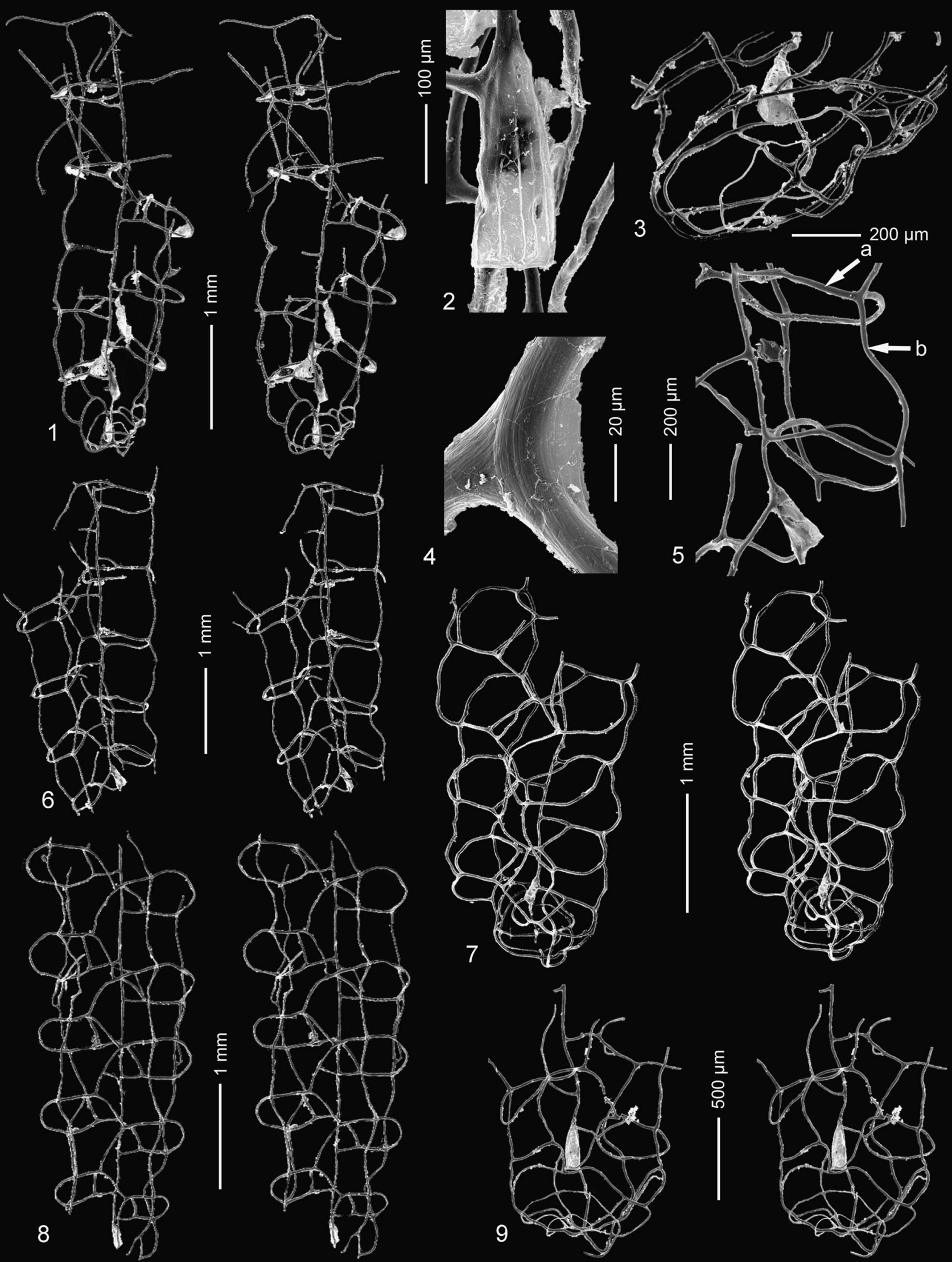


thecal rims. Of the almost 20 specimens of $R$. exutus described by Bates and Kirk (1992), none show any evidence of lateral apertural spines and only one shows evidence of a spine on the mid-ventral list (their fig. 107).

It is noteworthy that the Swedish collecting locality (Osmundsberg) of Hutt et al. (1970) is the same locality from which Bates and Kirk (1992) and Maletz (2014) obtained their material, although no information is provided as to whether they were collected from the same sample horizon. This suggests that there are two morphotypes present in those collections: those with spines and those without. These may be interpreted as either closely similar but distinct species or a case of intraspecific variation. Since the number of specimens is very limited, all specimens are incomplete and/or represented by immature fragments, and nothing is known of the distal portions of either form, it is not possible to state with confidence that these specimens all belong to a single species. A conservative approach is taken here, therefore, and the spinose forms are referred to Rotaretiolites cf. exutus.

\section{Genus Eorograptus Sennikov, 1984}

Type species.-Pseudoplegmatograptus singularis Sennikov, 1976, by original designation.

Diagnosis (emended from Sennikov, 1984).-Tubarium parallel-sided. Prosicula present, nema connected throughout to thecal lists by horizontal connecting rods and transverse rods. Thecal apertural lists looping, horizontal, alternating on either side in orderly, ladder-like succession. Pleural lists parallel, vertical on both sides of tubarium, continuous between each thecal aperture. Tubarium entirely of thecal framework lists; zigzag lists on reverse side.

Species included.-Eorograptus singularis (Sennikov, 1976), E. spirifer n. sp. (= "Paraplectograptus" of Lenz and Melchin, 1997), and possibly Dabashanograptus dubius Ge, 1990 (see Loydell, 1993, for comment).

Remarks.-The original generic diagnosis was based on incomplete, flattened specimens having only few remnants of the ancora umbrella. As a result, it is not possible to determine ancora umbrella form for the genus as a whole. Sennikov's (1984) specimens, however, clearly demonstrate that the post-ancora umbrella region of the Arctic and Siberian specimens are essentially identical, in that both possess a prosicula, parallel and continuous pleural lists, horizontal lateral thecal lists and looped apertural lists that alternate from side to side in a uniform, ladder-like succession, zigzag lists on the reverse side, and a lack of thecal mid-ventral lists.
Specimens of Eorograptus bear some resemblance to those of species of Paraplectograptus in their relatively simple thecal structure. They differ in that in Eorograptus the pleural lists are vertical and continuous between apertural lists and the lateral apertural rods are horizontal, whereas in those of Paraplectograptus, the pleural lists and lateral apertural rods are both inclined and form a zigzag. In addition, the ancora umbrellas of specimens of Eorograptus spirifer are moderately deep and bear spiral lists, whereas those of species of Paraplectograptus are a very simple, shallow structures generally composed of four radially arranged lists (see below for Paraplectograptus? sp.).

Eorograptus also has some similarities to our new genus, Aeroretiolites. One of the most significant differences, however, is that specimens of Eorograptus lack mid-ventral thecal lists, which are characteristic of both Aeroretiolites cancellatus and Aeroretiolites? sp.

Based on the illustrations of Dabashanograptus dubius in Ge (1990), and an occurrence of what is probably the same species in UK, Loydell (1993) suggested that D. dubius might, alternatively, be considered a species of Eorograptus. The known specimens of D. dubius, however, are poorly preserved and too incomplete, both in China and, especially, UK (including the lack of an ancora umbrella), for confident generic assignment.

\section{Eorograptus spirifer new species} Figure 13.1-13.9

\section{7 'Paraplectograptus' Lenz and Melchin, fig. 2c.}

Holotype.-Holotype GSC137645, from L. convolutus Zone, Cape Manning, Cornwallis Island. Paratypes GSC137646, 137646, from L. convolutus Zone, Cape Manning.

Diagnosis.—Prosicula present, ancora umbrella moderately deep with two to three whorls of spiral lists. Thecal apertural lists looping, horizontal. Pleural lists parallel, vertical. Nema attached to thecal framework by connecting rods, zigzag lists on reverse side. Tubarium narrow, up to $1.6 \mathrm{~mm}$ wide, 2TRD 1.28-1.68. No evidence of preserved ancora sleeve or mid-ventral lists.

Materials.—15 specimens, well preserved, although some specimens somewhat compressed and fragmentary.

Occurrence.—L. convolutus Zone, Cape Manning and Rookery Creek, Cornwallis Island.

Description.-Tubarium widening very gradually, increasing in width from 1.1 to $1.45 \mathrm{~mm}$ proximally to $1.6 \mathrm{~mm}$ distally, maximum length at least $4.5 \mathrm{~mm}$. 2TRD $1.28-1.68 \mathrm{~mm}$ 


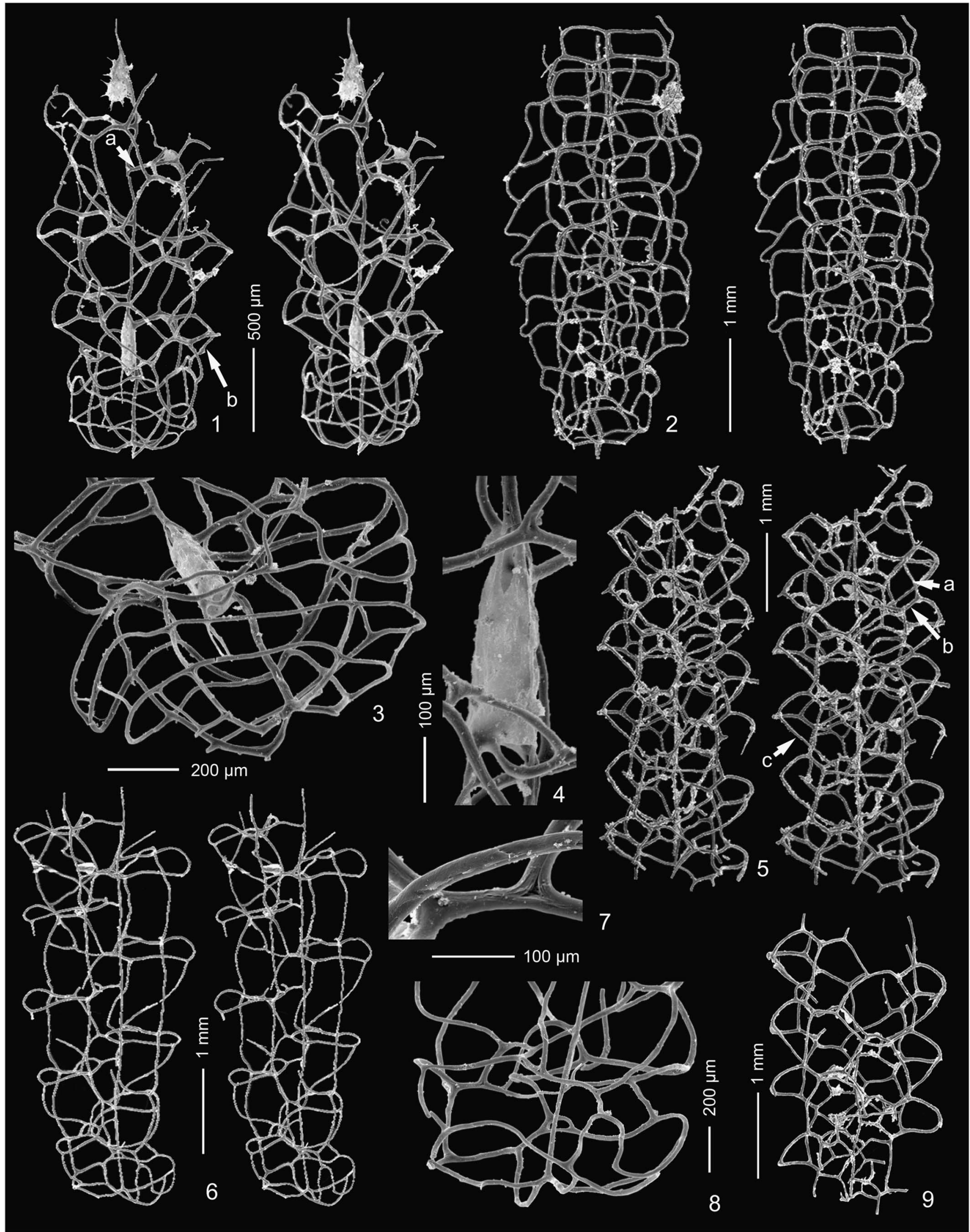


(15.7-12.4 $\mathrm{mm}$ in $10 \mathrm{~mm})$. Prosicula $0.25-0.35 \mathrm{~mm}$ long with longitudinal rods (Fig. 13.2), virgella $0.38 \mathrm{~mm}$ (one specimen). Ancora umbrella relatively shallow (below sicular aperture, accounting for compression), with two to three whorls of spiral lists, $\sim 0.85 \mathrm{~mm}$ wide across umbrella rim (Fig. 13.3). Rectangular ventral orifices on both walls. Thecal apertural lists horizontal, looping, alternating in position on opposite ventral walls in distinct, ladder-like succession. Zigzag list on reverse side, joining lateral apertural rods. Obverse side with only horizontal lateral apertural rods and vertical pleural lists. List micro-ornament of very fine, parallel striae (Fig. 13.4).

Etymology.—spirifer: L., spire-bearing; referring to the spiral lists that make up the ancora umbrella.

Remarks.-The very strong similarities of specimens of E. singularis and E. spirifer in terms of the structure of their thecal framework strongly suggest that they are congeneric. In comparing their morphometrics, however, they are quite different: E. singularis, which is earliest Telychian in age (S. guerichi Zone), is recorded by Sennikov (1984) as $1.8 \mathrm{~mm}$ wide measured between the pleural lists, but $\sim 2.5 \mathrm{~mm}$ inclusive of the apertural lists, whereas our specimens of E. spirifer measure a maximum of only $1.6 \mathrm{~mm}$, including looping apertural lips. In addition, the Siberian material has a thecal spacing of $12-11$ in $10 \mathrm{~mm}$ (=2TRD $1.65-1.8 \mathrm{~mm})$, whereas specimens of $E$. spirifer has much more closely spaced thecae (2TRD 1.28-1.68 mm, or 15.7-12 in $10 \mathrm{~mm}$ ). The absence of a complete ancora umbrella in the Altai material prevents further comparisons between the two geographically and temporally separated collections.

\section{Genus Aeroretiolites new genus}

Type species.—Aeroretiolites cancellatus n. sp. (= 'Rotaretiolites' sp. of Lenz and Melchin, 1997).

Other species.-Possibly Aeroretiolites? sp.

Diagnosis.—Ancora umbrella comprises radial lists with a continuous undulating rim with up to three whorls of spiral lists. Thecae with everted to horizontal apertural loops supported by slightly convex mid-ventral lists. Pleural lists present, joined to lateral apertural rods. Lists bear weak, parallel striations. Ancora sleeve weakly developed.

Etymology.-Aero: L, wicker basket; referring to the basket-like ancora umbrella.
Remarks.-Specimens of Aeroretiolites possess attributes of species of both Pseudoretiolites and Rotaretiolites. Like the former they possesses a bowl-like ancora umbrella with spiral lists (generally markedly smaller than those of Pseudoretiolites), and a micro-ornament of very fine striae, unlike the relatively coarse parallel ridges seen in specimens of Rotaretiolites. Like Rotaretiolites, each theca is floored by a single, simple, slightly convex mid-ventral list that meets a looping apertural lip.

\section{Aeroretiolites cancellatus new species}

Figure 14.1-14.5, 14.9

\section{7 'Rotaretiolites' Lenz and Melchin, fig. 2b.}

Holotype.-Holotype GSC137651, from the L. convolutus Zone, Cape Manning, Cornwallis Island. Paratypes GSC137652-137654.

Diagnosis.-Ancora umbrella moderately shallow with two to three whorls of spiral lists. Prosicula normally preserved. Nema attached to transverse rods by connecting rods. Thecae comprise everted to horizontal apertural loops connected to mid-ventral lists. Mid-ventral lists slightly convex outward and inclined. Pleural lists present, vertical to slightly inclined and joined to lateral apertural rods. Lists bear weak, parallel striations. Reticulum of ancora sleeve limited in development, with very coarse meshes on both lateral walls.

Materials.-14 specimens; two are complete, several have a well-preserved ancora umbrella, and others in which the distal portion remains, but are without the ancora umbrella.

Occurrence.-L. convolutus Zone, Cape Manning, Cornwallis Island, and Dundas Island.

Description.-Tubarium gradually widening proximally and becoming parallel-sided, at least $5.8 \mathrm{~mm}$ long, width across first thecal pair $1.0-1.1 \mathrm{~mm}$ and $1.8-2.15 \mathrm{~mm}$ distally. $2 \mathrm{TRD}$ $1.25-1.6 \mathrm{~mm}(16-12.5$ in $10 \mathrm{~mm})$ proximally, and $1.3-1.6 \mathrm{~mm}$ distally (two specimens). Prosicula 0.35 long, virgella $0.40-0.45 \mathrm{~mm}$, with longitudinal rods. Ancora umbrella moderately shallow, reaching a level just below the aperture of the prosicula, bowl-shaped, with two or three whorls of spiral lists, width $0.8-0.9 \mathrm{~mm}$. A large ovate lateral orifice on each wall. Thecal apertural lips comprise everted to horizontal, looping lists, attached to slightly convex mid-ventral lists inclined to nema $30^{\circ}-45^{\circ}$. Mid-ventral list of theca $1^{1}$ connected to rim of ancora umbrella. Lateral aperture rods curved, pleural lists vertical to variably, slightly inclined. Zigzag lists on reverse side, nema

Figure 14. Scanning electron microscopy images of Aeroretiolites cancellatus n. gen. n. sp. and Aeroretiolites? sp. (1-5, 9) Aeroretiolites cancellatus n. gen. n. sp.: $(\mathbf{1}, \mathbf{3}, \mathbf{4})$ holotype GSC137651, (1) stereopair of well-preserved specimen with three thecal pairs and ancora umbrella with three spiral whorls, prosicula, attachment of nema to connecting rods (a), and attachment of base of mid-ventral list of theca $1^{1}$ (b) to ancora umbrella rim, (3) proximo-lateral view of ancora umbrella and prosicula, (4) sicula, showing fine longitudinal rods, note also smooth to finely striated list surfaces, section MCM88-10, 6.5, L. convolutus Zone; (2) paratype GSC137652, stereopair of ventrally flattened specimen with two whorls of spiral lists on ancora umbrella and large lateral orifice; (5) paratype GSC137653, stereopair of distal portion of mature specimen with seven thecal pairs, moderate ancora sleeve, showing sloping pleural lists (a), lateral apertural rods (b), mid-ventral lists (c), section MCM2-98, 54.0-54.15, L. convolutus Zone; (9) paratype GSC137654, distal specimen of tubarium, with four thecal pairs and ancora sleeve, section MCM2-98, 54.0-54.15, L. convolutus Zone. (6-8) Aeroretiolites? sp.: GSC137655, (6) stereopair of very well preserved, complete specimen with five pairs of thecae, a shallow ancora umbrella without spiral lists, and parallel and continuously connected pleural lists, (7) enlargement of list surfaces showing smooth to finely striated microstructure, (8) oblique proximal view showing simple ancora structure, section MCM2-98, 54.0-54.15, L. convolutus Zone. 

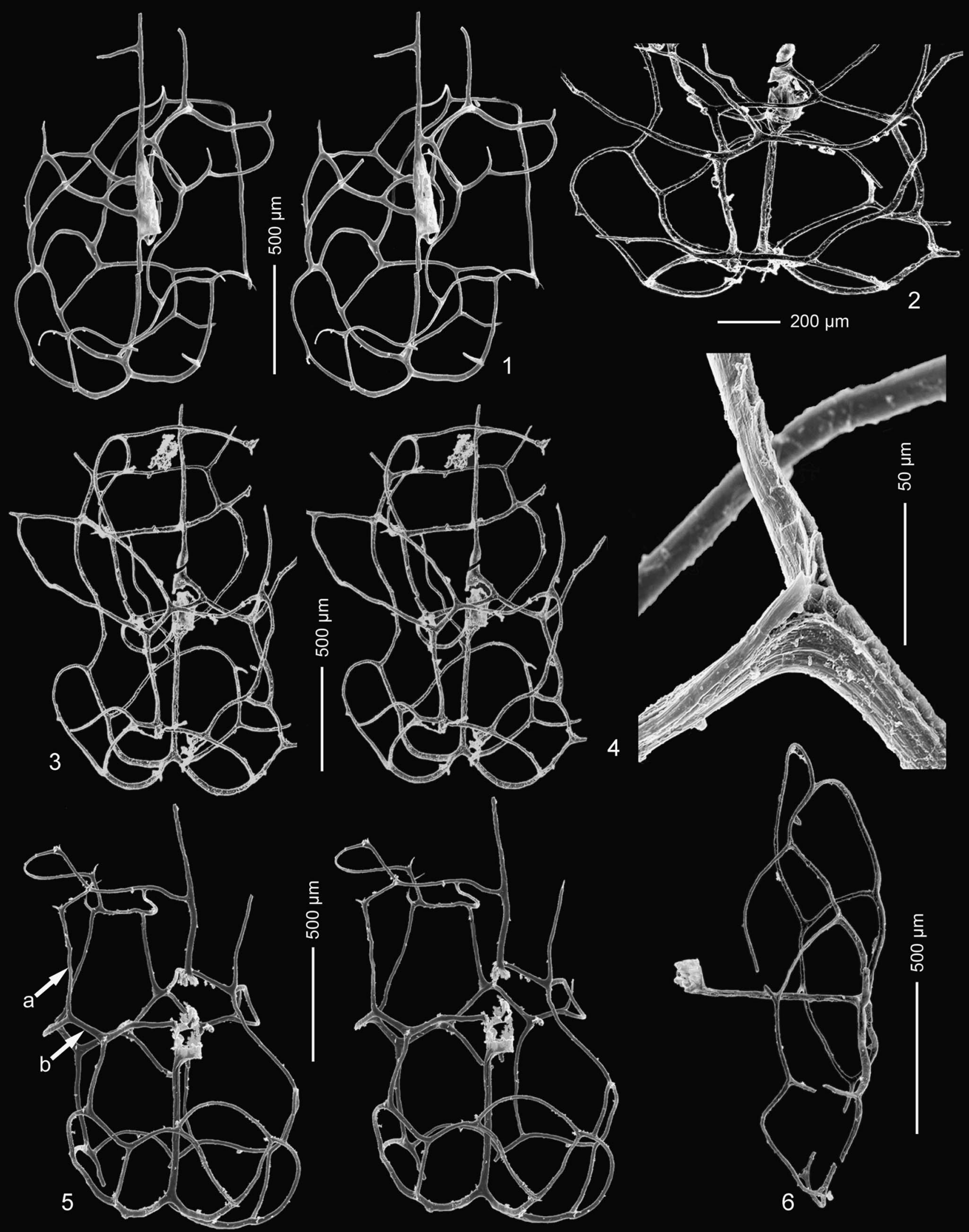
attached to transverse rods by connecting rods. Ancora sleeve of very large meshes, better developed on reverse side, seams facing out. No evidence of the presence of stomata. List surfaces smooth to very finely striated.

Etymology.—cancellatus: L; cross-barred, lattice; referring to basket-like ancora umbrella.

Remarks._See remarks for genus and for Aeroretiolites? sp.

Aeroretiolites? sp.

Figure 14.6-14.8

Materials.-One very well-preserved, mature specimen with a complete ancora umbrella.

Occurrence.-L. convolutus Zone from Cape Manning, Cornwallis Island.

Description.-Tubarium of five thecal pairs, widening gradually from $1.2 \mathrm{~mm}$ across ancora umbrella to a maximum of $1.88 \mathrm{~mm}$ distally. 2TRD $1.75-2.0 \mathrm{~mm}$. Prosicula not preserved, prosicular interval and virgella $\sim 1.2 \mathrm{~mm}$ long. Ancora umbrella simple and very shallow, with four radial lists, saucer shaped, with an irregular rim. Mid-ventral lists moderately inclined, slightly convex. Mid-ventral list of theca $1^{1}$ attached to rim of umbrella; distal mid-ventral lists relatively long, slightly convex. Ventral side orifice present under theca $1^{2}$, none under theca $1^{1}$. Thecal lateral apertural rods and looping apertural rim horizontal. Nema attached by connecting rods to transverse rods. Zigzag lists define reverse wall. Pleural lists connected to each other directly at lateral apertural rods, and are parallel to each other on both lateral walls. No ancora sleeve. List surfaces smooth to very finely striated.

Remarks.—Aeroretiolites? sp. is a represented by only a single, very well-preserved specimen that is similar in most respects to Aeroretiolites cancellatus. It differs, however, in its possession of a simpler and shallower ancora umbrella without spiral lists, pleural lists that are straight, vertical and continuously connected, and thecal apertural rims that are horizontal. In addition, the single specimen shows no prosicula or ancora sleeve lists, although these features are sometimes inconsistently preserved in some retiolitines. Considering that there is only a single specimen, we identify it as Aeroretiolites? sp.

The specimen of Aeroretiolites? sp. appears similar in many respects to those of Eorograptus spirifer but differs in that the former possesses mid-ventral thecal lists and lacks spiral lists on the ancora.

\section{Genus Paraplectograptus Příbyl, 1948}

Type species.-Retiolites eiseli Manck, 1917, by original designation.

\author{
Paraplectograptus? sp. \\ Figure 15.1-15.6
}

Materials.-Nine fragmentary, somewhat compressed specimens, all immature, of which five are well preserved, and most complete consists of ancora umbrella and up to three thecae.

Occurrence.-S. guerichi Zone, Snowblind Creek and Rookery Creek, Cornwallis Island. Three additional questionable specimens from Snowblind Creek and one questionable specimen from the L. convolutus Zone at Cape Manning.

Description.—Sicula $0.4-0.49 \mathrm{~mm}$ long, virgella $0.6-0.7 \mathrm{~mm}$, prosicula partially to completely preserved, with longitudinal rods. Ancora umbrella simple, shallow, consisting of four radial lists that may divide distally, with complete, undulatory rim, $1.2-1.5 \mathrm{~mm}$ wide. Openings under theca $1^{2}$ about twice as large as that under theca $1^{1}$. Transverse rods present. Pleural lists inclined slightly, connected to lateral apertural list declined strongly outwardly, and to horizontal apertural rim. Apertural lips looped, horizontal. No thecal mid-ventral lists. Nema attached to connecting rods. Zigzag lists on reverse side, outside of which are a few weak ancora sleeve lists; none observed on obverse side. List micro-ornament smooth or weakly longitudinally striated.

Remarks.-These specimens may represent a new species, possibly representing a new genus, but because of the limited number of distorted specimens, and their immaturity, they are questionably referred to the genus Paraplectograptus, with which they share a similar ancora umbrella and tubarium construction (see Bates et al., 2005, fig. 6F). Our phylogenetic analysis (see above) suggests that this is a stem taxon to the clade that includes Paraplectograptus, Sokolovograptus and all of the more derived species previously regarded as "plectograptines." Paraplectograptus? sp. appears to consistently possess a preserved prosicula. Its micro-ornamentation consists of fine parallel striae, in contrast to the pustular ornamentation of Paraplectograptus s.s. and more derived "plectograptines."

\section{Acknowledgments}

M.J.M and A.C.L. acknowledge the long-term financial support from Natural Sciences and Engineering Research Council (Canada) (NSERC), and logistical support from the Polar Continental Shelf Project. A.K. acknowledges a financial grant from Ministerstwo Nauki i Szkolnictwa Wyższego decision number 499/N (Poland) and collaborative support from NSERC 2009/0. Field support from A. McCracken, M. Coniglio, J. Lukasik, J. Russel-Houston, E. MacDonald, P. Noble, 
S. Senior, S. Poulson, and the late D. Perry is gratefully acknowledged. We thank A. Hołda-Michalska for assistance with preparation of the figures, and D. Bates, C.E. Mitchell, and an anonymous reviewer for their very helpful comments ad suggestions. The paper is a contribution to IGCP591: The Early to Middle Paleozoic Revolution.

\section{Accessibility of supplemental data}

\section{Data available from the Dryad Digital Repository: https://doi.org/10.1017/jpa.2016.107}

\section{References}

Barrrande, J., 1850, Graptolites de Bohême. VI, Prague, Author.

Bates, D.E., and Kirk, N.H., 1992, The ultrastructure, mode of construction and functioning of a number of Llandovery ancorate diplograptid and retiolitid graptolites: Modern Geology, v. 17, p. 1-270.

Bates, D.E., and Kirk, N.H., 1997, The ultrastructure, construction and functioning of the genera Stomatograptus and Retiolites, with an appendix on the incremental construction of the rhabdosome in Petalolithus, and its comparison with that of the thecal framework in Retiolites and in Stomatograptus: Institute of Geography and Earth Sciences, University of Wales, Aberystwyth, Publication, v. 10, 168 p.

Bates, D.E.B., Kozłowska, A., and Lenz, A.C., 2005, Silurian retiolitid graptolites: Morphology and evolution: Acta Palaeontologica Polonica, v. 50, p. 705-720.

Bjerreskov, M., 1975, Llandoverian and Wenlockian graptolites from Bornholm: Fossils and Strata, v. 94, p. 1-94.

Bouček, B., 1944, O nekterych ostnitych diplograptidech českeho a saského Siluru: Rozpravy Česk. Akademie věd a uměni, Třidy II, v. 53, p. 1-6.

Bouček, B., and Münch, A., 1944, Die Retioliten des mitteleuropäischen Llandovery und unteren Wenlock: Mitteilungen der tschechischen Akademie der Wissenschaft, v. 43, p. 1-54.

Bouček, B., and Münch, A., 1952, The Central European Retiolites of the Upper Wenlock and Ludlow: Sborník ústředního ústavu geologického. Oddil paleontologický, v. 19, 151 p.

Bulman, O.M.B., 1970, Graptolithina, with sections on Enteropneusta and Pterobranchia, in Moore, R.C., ed., Treatise on Invertebrate Paleontology, Second Edition, Part V., Boulder, Colorado and Lawrence, Kansas, Geological Society of America (and University of Kansas Press), p. V1-V163.

Chen, X., 1984, Silurian graptolites from southern Shaanxi and northern Sichuan with special reference to classification of Monograptidae: Palaeontologia Sinica, New Series B, v. 166, No. 20, 102 p. [in Chinese with English summary]

Chen, X., and Lin, Y.K., 1978, Lower Silurian graptolites from Tongzi, northern Guizhou: Memoir of the Nanjing Institute of Geology and Paleontology, Academia Sinica, v. 12, p. 1-76. [in Chinese with English summary]

Dawson, D.H., 2007, Morphology and phylogeny of some Llandovery (Lower Silurian) monograptid graptolites from Arctic Canada [M.Sc. thesis]: Antigonish, St. Francis Xavier University, $176 \mathrm{p}$

Donoghue, P.C., Purnell, M.A., Aldridge, R.J., and Zhang, S., 2008, The interrelationships of "complex" conodonts (Vertebrata): Journal of Systematic Palaeontology, v. 6, p. 119-153.

Elles, G.L., and Wood, E.M.R., 1908, Monograph of British Graptolites, Part VII: Palaeontographical Society Monograph, v. 62, p. 273-358.

Ge, M.Y., 1990, Silurian graptolites from Chengkou, Sichuan: Palaeontologia Sinica, New Series B, v. 179, No. 26157 p. [in Chinese with English summary]

Goloboff, P.A., Farris, J.S., and Nixon, K.C., 2008, TNT, a free program for phylogenetic analysis: Cladistics, v. 24, p. 774-786.

Howe, M.P.A., 1983, Measurement of thecal spacing in graptolites: Geological Magazine, v. 120 , p. 635-638.

Hutt, J.E., 1974, The Llandovery graptolites of the English Lake District, Part 1: Palaeontographical Society Monographs, p. 1-56.

Hutt, J.E., Rickards, R.B., and Skevington, D., 1970, Isolated Silurian graptolites from the Bollerup and Klubbudden stages of Dalarna, Sweden: Geologica et Palaeontologia, v. 4, p. 1-23.

Koren', T.N., and Rickards, R.B., 1996, Taxonomy and evolution of Llandovery biserial graptoloids from the southern Urals, western Kazakhstan: Special Papers in Palaeontology, v. 54, 103 p.

Kozłowska-Dawidziuk, A., 1995, Silurian retiolitids of the East European Platform: Acta Palaeontologica Polonica, v. 40, p. 261-326.
Kozłowska-Dawidziuk, A., 2004, Evolution of retiolitid graptolites-a synopsis: Acta Palaeontologica Polonica, v. 49, p. 505-518.

Kozłowska-Dawidziuk, A., and Lenz, A.C., 2001, Evolutionary developments in the Silurian Retiolitidae (Graptolites): Journal of the Czech Geological Society, v. 46, p. 227-238.

Lapworth, C., 1873, On an improved classification of the Rhabdopora: Geological Magazine, v. 10, p. 500-504. 555-560.

Lapworth, C., 1877, On the graptolites of County Down: Belfast Natural Field Club, Proceedings, v. 1, p. 125-144.

Lenz, A.C., 1982, Llandoverian graptolites of the northern Canadian Cordillera: Petalograptus, Cephalograptus, Rhaphidograptus, Dimorphograptus, Retiolitidae, and Monograptidae: Royal Ontario Museum Life Sciences Contribution, v. 130, p. 154.

Lenz, A.C., 1988, Upper Llandovery and Wenlock graptolites from Prairie Creek, southern Mackenzie Mountains, Northwest Territories: Canadian Journal of Earth Sciences, v. 25, p. 1955-1971.

Lenz, A.C., 1993, Late Wenlock and Ludlow (Silurian) Plectograptinae (Retiolitid Graptolites), Cape Phillips Formation, Arctic Canada: Bulletins of American Paleontology, v. 104, 52 p.

Lenz, A.C., and Kozłowska, A., 2007, New and unusual upper Llandovery graptolites from Arctic Canada: Acta Palaeontologica Polonica, v. 52, p. 489-502.

Lenz, A.C., and Kozłowska-Dawidziuk, A., 2001, Upper Wenlock graptolites of Arctic Canada: pre-extinction, lundgreni Zone fauna: Palaeontographica Canadiana, v. 20,61 p.

Lenz, A.C., and Melchin, M.J., 1987a, Silurian retiolitids from the Cape Phillips Formation, Arctic Islands, Canada: Bulletin of the Geological Society of Denmark, v. 35, p. 161-170.

Lenz, A.C., and Melchin, M.J., 1987b, Periderm and interthecal tissue in Silurian retiolitid graptolites: with examples from Sweden and Arctic Canada: Lethaia, v. 20, p. 353-359.

Lenz, A.C., and Melchin, M.J., 1997, Phylogenetic analysis of the Silurian Retiolitidae (graptolites): Lethaia, v. 29, p. 301-309.

Lenz, A.C., and Thorsteinsson, R., 1997, Fusellar banding in Silurian retiolitid graptolites: Journal of Paleontology, v. 71, p. 917-920.

Lenz, A.C., Cuerda, A., and Peralta, S., 2003, Graptolites from the upper Llandovery of the Talacasto area, Central Cordillera, San Juan, Argentina: Journal of Paleontology, v. 77, p. 1198-1202.

Lenz, A., Senior, S., Kozłowska, A., and Melchin, M.J., 2012, Graptolites from the mid Wenlock (Silurian), middle and upper Sheinwoodian, Arctic Canada: Palaeontographica Canadiana, v. 32, 93 p.

Li, J.J., 1995, Lower Silurian graptolites from the Yangtze Gorge District: Palaeontologia Cathayana, v. 6, p. 215-344. [in Chinese with English summary]

Loydell, D.K., 1993, Upper Aeronian and lower Telychian (Llandovery) graptolites from western mid-Wales, Part 2: Palaeontographical Society Monograph, p. 56-180.

Loydell, D.K., 2012, Graptolite Zone correlation charts: Geological Magazine, v. 149 , p. $124-132$.

Lukasik, J.J., and Melchin, M.J., 1997, Morphology and classification of some early Silurian monograptids (Graptoloidea) from the Cape Phillips Formation, Canadian Arctic Islands: Canadian Journal of Earth Sciences, v. 34, p. $1128-1149$.

Maddison, W.P., and Maddison, D.R., 2003, MaClade Version 4.06. Analyses of Phylogeny and Character Evolution: Sinauer Associates, Massachusetts.

Maletz, J., 2014, The classification of the Pterobranchia (Cephalodiscida and Graptolithina): Bulletin of Geosciences, v. 89, p. 477-540.

Manck, E., 1917, Die Graptolithen der Zone 18, sowie Retiolites eiseli, sp. n. Zeitschrift für Naturwissenschaft, v. 86, p. 337-344.

Melchin, M.J., 1989, Llandovery graptolite biostratigraphy and paleobiogeography, Cape Phillips Formation, Canadian Arctic Islands: Canadian Journal of Earth Sciences, v. 26, p. 1726-1746.

Melchin, M.J., 1998, Morphology and phylogeny of some Early Silurian "diplograptid" genera from Cornwallis Island, Arctic Canada: Palaeontology, v. 41, p. 263-315.

Melchin, M.J., 1999, Origin of the Retiolitidae: insights from a new graptolite genus from the early Silurian of Arctic Canada: Lethaia, v. 32, p. 261-269.

Melchin, M.J., 2013, A view of the Rhuddanian-Aeronian boundary from Arctic Canada, in Lindskog, A., and Mehlqvist, K., eds., Proceedings of the 3rd IGCP 591 Annual Meeting - Lund, Sweden, 9-19 June 2013, p. 217-218.

Melchin, M.J., and Holmden, C., 2006, Carbon isotope chemostratigraphy of the Llandovery in Arctic Canada: implications for global correlation and sea-level change: GFF, v. 128, p. 173-180.

Melchin, M.J., Koren', T.N., and Štorch, P., 1998, Global diversity and survivorship patterns of Silurian graptoloids, in Landing, E., and Johnson, M.E., eds., Silurian Cycles. Linkages of Dynamic Stratigraphy with Atmospheric, Oceanic, and Tectonic Cycles. James Hall Volume: New York State Museum Bulletin, v. 491, p. 165-182. 
Melchin, M.J., Mitchell, C.E., Naczk-Cameron, A., Fan, J.X., and Loxton, J., 2011, Phylogeny and adaptive radiation of the Neograptina (Graptoloida) during the Hirnantian extinction and Silurian recovery: Proceedings of the Yorkshire Geological Society, v. 58, p. 1-30.

Mirande, J.M., 2009, Weighted parsimony phylogeny of the family Characidae (Teleostei: Characiformes): Cladistics, v. 25, p. 574-613.

Mitchell, C.E., Melchin, M.J., Cameron, C.B., and Maletz, J., 2013, Phylogenetic analysis reveals that Rhabdopleura is an extant graptolite: Lethaia, v. 46, p. $34-56$.

Münch, A., 1952, Die Graptolithen aus dem anstehenden Gotlandium Deutschland und der Tschechoslowakei: Geologica, v. 7, p. 1-157.

Nicholson, H.A., 1868, On the graptolites of the Coniston Flags; with notes on the British species of the genus Graptolites: Quarterly Journal of the Geological Society of London, v. 24, p. 521-545.

Obut, A.M., and Sobolevskaya, R.F., 1967, Graptolity, in Obut, A.M., Sobolevskaya, R.F., and Nikolaev, A.N., eds., Graptolity i stratigrafiya nizhnego Silura okrainnykh podnyatiy Kolymskogo Massifa, Akademiya Nauk, SSSR, Sibirskoe otdelenie, Institut Geologii i Geofiziki, p. 46-162. [in Russian]

Obut, A.M., and Sobolevskaya, R.F., 1968, Opisanie graptolitov, in Obut, A.M., Sobolevskaya, R.F., and Merkur'eva, A.P., eds., Graptoliti Llandoveri v Vernakh Burovykh Skvazhni Noril'skogo Raïona, Akademia Nauk SSSR, Sibirskoe otdelenie, Institut Geologii i Geofiziki, p. 57-136. [in Russian]

Obut, A.M., and Zaslavskaya, N.M., 1983, Semeyestva retiolitid i ikh filogeneticheskie otnosheniya, in Dagys, A.S., and Dubatolov, V.N., eds., Morphologiya i Sistematika Bespozvonochnykh Fanerozoya: Akademia Nauk SSSR, Sibirskoe otdelenie, Instytut Geologii i Geofiziki, Izdotelstvo "Nauk", Moscow, p. 103-113. [in Russian]

Př́byl, A., 1948, Bibliographic index of Bohemian Silurian graptolites: Knihovna Státního Geologického ústavu Republiky Československé, v. 22, p. 1-97.

Richter, R., 1853, Thüringer Graptolithen: Zeitschrift der Deutschen Geologischen Gesellschaft, v. 5, p. 439-464.

Rickards, R.B., 1976, The sequence of graptolite zones in the British Isles: Geological Journal, v. 11, p. 153-188.

Rickards, R.B., and Koren', T.N., 1974, Virgellar meshworks and sicular spinosity in Llandovery graptoloids: Geological Magazine, v. 111, p. 193-204.

Schauer, M., 1971, Biostratigraphie und Taxionomie der Graptolithen des tieferen Silurs unter besonderer Berücksichtigung der tektonischen Deformation: Freiberge Forschungshefte, Paläontologie, C, v. 273, 185 p.

Sennikov, N.V., 1976, Graptolity i stratigrafii nizhnego silura Altaya: Akademiya Nauk SSSR, Sibirskoe otdelenie, Trudy Instituta Geologii i Geofiziki, v. 304, p. 1-230. [in Russian]

Sennikov, N.V., 1984, Nekotorye retiolitidy (graptolity) gornogo Altaya: Akademiya Nauk SSSR, Sibirskoe otdelenie, Trudy Instituta Geologii i Geofiziki, v. 584, p. 48-55. [in Russian]

Štorch, P., 1985, Orthograptus s.l. and Cystograptus (Graptolithina) from the Bohemian lower Silurian: Vestnik Ústredniho ústavu geologického, v. 60, p. $87-100$

Štorch, P., 1998, Graptolites of the Pribylograptus leptotheca and Lituigraptus convolutus zones of Tmañ (Silurian, Czech Republic): Journal of the Czech Geological Society, v. 43, p. 209-272.

Štorch, P., and Frýda, J., 2012, The late Aeronian graptolite sedgwickii Event, associated positive carbon isotope excursion and facies changes in the Prague Synform (Barrandian area, Bohemia): Geological Magazine, v. 149, p. 1089-1106.

Swofford, P., 2002, Phylogenetic Analyses Using Parsimony (PAUP) Version 4.0b10. Illinois Natural History Survey, Champaign.

Tomczyk, H., Urbanek, A., and Teller, L., 1991, Typ Hemichordata. Class Graptolithina, in Pajchlowa, M., ed., Geology of Poland, Vol. III, Atlas of Guide and Charateristic Fossils, pt. 1a, Paleozoic, Warsaw, Publishing House Wydawnictwa Geologiczne, p. 297-321.

Tullberg, S.A., 1883, Skånes graptoliter: Sveriges Geologiska Undersökning, Series C, v. 55 , p. $1-43$.

Zalasiewicz, J.A., Taylor, L., Rushton, A.W.A., Loydell, D.K., Rickards, R.B., and Williams, M., 2009, Graptolites in British stratigraphy: Geological Magazine, v. 146, p. 785-850.

\section{Appendix 1. Aeronian and lower Telychian retiolitine graptolite locality information}

Collections studied listed by locality and numbered SEM stubs and unmounted specimen collections from each locality. Codes given in brackets (e.g., MCM88-8, 11.5A) are field-designated locality and collection codes; numbers after taxon names are the numbers of specimens of each species.
Cape Manning.-This section was collected in several different years. Most of the collections can be correlated to the 1992 (CM) meterages, which are shown with the measured lithologic $\log$ in Figure 3. Samples are listed below by meters above the base of the 1992 measured section, along with the original field codes. Some collections (those coded as ML64 and MCM X 91A) were reconnaissance samples collected quickly in the vicinity of the measured section, but cannot be precisely placed within the lithologic log. Zonal designations of these samples are based on the associated fauna within each concretion.

CM 44.0-44.1 - Stub 21 (MCM 98, 44.0-44.1) - Pseudoretiolites? sp. - 3: D. triangulatus/D. pectinatus Subzone

CM 49.5 m - Unmounted - MCM88-8, $11.5 \mathrm{~m}$ - Pseudoretiolites? sp.. - 8: upper D. triangulatus/D. pectinatus Subzone or lower R. orbitus Subzone

CM 49.5 m - Stub 1 (MCM 88-8, 11.5B) -Pseudoretiolites? sp. - 5: upper D. triangulatus/D. pectinatus Subzone or lower $R$. orbitus Subzone

CM 49.5 m - Stub 2 (MCM 88-8, 11.5B) - Pseudoretiolites? sp. - 9: upper D. triangulatus/D. pectinatus Subzone or lower $R$. orbitus Subzone

CM 49.5 m - Stub 20 (MCM 88-8, 11.5) - Pseudoretiolites? sp. - 1: upper $D$. triangulatus $/ D$. pectinatus Subzone or lower $R$. orbitus Subzone

CM 49.8-49.9 - Stub 6 (MCM96.9, 1.6-1.7 below) Pseudoretiolites? sp. - 4: $R$. orbitus Subzone

CM 52.6-52.7 - Stub 7 (MCM96.9, 1.6-1.7 above) Pseudoretiolites hyrichus n. sp. - 6: R. orbitus Subzone

CM 53.2-53.3 - Stub 13 (MCM96-9, 1.8-1.9 above) Pseudoretiolites hyrichus n. sp. - 4: L. convolutus Zone

CM 54.0-54.15 - Stub 8 (MCM2-98, 54.0-54.15) Aeroretiolites cancellatus - 6: L. convolutus Zone

CM 54.0-54.15 - Stub 19 (MCM2-98, 54.0-54.15) Aeroretiolites cancellatus - 4: L. convolutus Zone

CM 55.0 - Stub 17 (MCM96-9, 3.6A) - Aeroretiolites? sp. - 1; Pseudoretiolites cf. tianbaensis - 2: L. convolutus Zone

CM 56.0 - Stub 18 (MCM96-9, 4.6A (56)) Pseudoretiolites cf. tianbaensis - 1: L. convolutus Zone

CM 59.1-59.2 - Stub 15 (MCM2-98, 59.1-59.2) Pseudoretiolites perlatus - 2: L. convolutus Zone

CM 59.1-59.2 - Stub 16 (MCM2-98, 59.1-59.2) Pseudoretiolites perlatus - 4: L. convolutus Zone

CM 62.0 - Stub 10 (MCM88-10, 6.0) - Eorograptus spirifer - 3; Pseudoplegmatograptus? sp. - 1: L. convolutus Zone

CM 62.0 - Stub 11 (MCM88-10, 6.0) - Eorograptus spirifer - 6: $L$. convolutus Zone

CM 62.2 - Stub 14 (MCM88-10, 6.2) - Eorograptus spirifer - 5: L. convolutus Zone

CM 62.5 - Stub 9 (MCM88-10, 6.5) - Aeroretiolites cancellatus 1: L. convolutus Zone

Stub 12 (ML64 upper) - Paraplectograptus? sp.? - 1: L. convolutus Zone

Stub 350 (ML64, 2): Pseudoretiolites? sp. - 3: L. convolutus Zone?

Stub 353 (ML64-85, 2): Pseudoretiolites cf. decurtatus - 2: $R$. orbitus Subzone 
Stub 361 (ML64-85, 2: Pseudoretiolites decurtatus - 3: $R$. orbitus Subzone

Unmounted - ML64 lower - Pseudoretiolites cf. decurtatus 4: $R$. orbitus Subzone?

Unmounted - MCM X 91A - Pseudoretiolites cf. decurtatus -

3, Pseudoretiolites hyrichus - 1: L. convolutus Zone

Dundas Island.-All samples are from the 25.7-26.2 $\mathrm{m}$ level in the section described and figured by Lukasik and Melchin (1997, fig. 2).

Stub 3 (DIS92-11, 17.5-18.0, sieve 3) - Aeroretiolites cancellatus - 3: L. convolutus Zone

Stub 4 (DIS92-11, 17.5-18.0, sieve 4) - Pseudoretiolites perlatus - 2: L. convolutus Zone

Stub 5 (DIS92-11, 17.5-18.0, sieve 5A) - Aeroretiolites cf. cancellatus - 4: L. convolutus Zone

Snowblind Creek.-One sample (MSC07, $3 \mathrm{~m}$ above 01G) is from the $213 \mathrm{~m}$ level in the section documented in Melchin (1989, fig. 2). The remaining samples (coded as LL1, LL3, and SB) are from reconnaissance collections that cannot be correlated precisely to the measured section. Zonal designations of these samples are based on the associated fauna within each concretion.

Unmounted - MSC07, $3 \mathrm{~m}$ above 01G: Rotaretiolites cf. exutus - 1; Pseudoplegmatograptus obesus - 1; Pseudoretiolites cf. tianbaensis - 1: S. guerichi Zone.

Stub 347 (LL1-77): Pseudoretiolites cf. tianbaensis - 1; Paraplectograptus? sp. - 4: S. guerichi or turriculatus Zone

Stub 354 (LL1B): Pseudoretiolites cf. tianbaensis - 1: S. guerichi or turriculatus Zone

Stub 356 (LL1-77): Paraplectograptus? sp. - 4; Rotaretiolites cf. exutus - 1: S. guerichi or turriculatus Zone

Stub 357 (LL1-77): Paraplectograptus? sp. - 1: S. guerichi or turriculatus Zone

Stub 358 (LL3A-77): Pseudoplegmatograptus obesus - 1: S. turriculatus Zone

Stub 359 (LL3-77): Pseudoplegmatograptus obesus - 1: S. turriculatus Zone

Unmounted - LL1-77 - Pseudoretiolites cf. tianbaensis - 5; Pseudoplegmatograptus obesus - 3; Rotaretiolites cf. exutus - 1: S. guerichi or turriculatus Zone

Unmounted - SB-G2 - Pseudoretiolites cf. tianbaensis - 5: S. guerichi Zone

Rookery Creek.-All of the present samples are from reconnaissance collections, which were collected near the measured section described by Melchin (1989), likely corresponding to a level within the covered interval between levels $\mathrm{A}$ and $\mathrm{B}$ (Melchin 1989, fig. 2). Zonal designations of these samples are based on the associated fauna within each concretion.

Stub 352 (MRC02): Pseudoretiolites cf. decurtatus - 1; Pseudoretiolites perlatus - 1; Eorograptus spirifer - 2: L. convolutus Zone

Stub 355 (MRC02, top C): Pseudoretiolites decurtatus - 1: L. convolutus Zone

Stub 362 (MRC-02): Pseudoretiolites decurtatus? - 3: L. convolutus Zone
Unmounted - MRC02 - Pseudoretiolites cf. perlatus - 4: L. convolutus Zone

Cape Sir John Franklin.-This collection is a reconnaissance sample collected within an interval of intermittent exposure below the Wenlock-Ludlow succession documented from this locality by Lenz (1993). Zonal designation of this sample is based on the associated fauna within the concretion.

Stub 348 (SJF02, 1C): Pseudoretiolites cf. tianbaensis - 1: guerichi Zone?

Unknown GSC locality, Cornwallis Island.-Zonal designations of these samples are based on the associated fauna.

Stub 351 (unknown GSC locality, Cornwallis Island): Pseudoretiolites decurtatus - 4: R. orbitus Subzone or L. convolutus Zone

Stub 363 (unknown GSC locality, Cornwallis Island): Pseudoretiolites perlatus - 3: L. convolutus Zone?

Stub 360 (unknown GSC locality, Cornwallis Island): Pseudoretiolities decurtatus - 3: L. convolutus Zone?

Stub 364 (unknown GSC locality, Cornwallis Island): Pseudoplegmatograptus? sp. - 1: L. convolutus Zone?

\section{Appendix 2. Characters and character states for phylogenetic analysis}

For definitions of most morphological terms, see Bates et al. (2005).

1. ancora umbrella development - 0: radial and spiral lists; 1: radial but no spiral lists; 2: hexagonal/pentagonal mesh.

2. ancora umbrella depth - 0: deep (ancora umbrella rim encloses the rim/aperture of the prosicula); 1: shallow (ancora umbrella rim occurs below the rim/aperture of the prosicula).

3 . thecal wall preservation - 0: complete thecal walls in all growth stages; 1: thecal framework of lists, but ventral thecal walls preserved in some mature specimens; 2: thecal frame work of lists only.

4. prosicula preservation - 0 : complete; 1 : completely preserved in some specimens; 2: prosicular rim preserved as a ring; 3 : virga only.

5. metasicula preservation - 0 : complete; 1 : partial; 2 : not preserved.

6. nema attachment to connecting rods -0 : not attached; 1 : attached.

7. thecal profile - 0: straight, inclined ventral thecal walls; 1 : inclined, convex ventral thecal walls; 2: geniculate ventral thecal walls.

8. basal connection of mid-ventral list of th $1^{1}-0$ : at virgella; 1 : at rim of ancora umbrella; 2: within inside surface of ancora umbrella; 3 - no mid-ventral list at th $1^{1}$.

9. distal mid-ventral thecal lists - 0: absent; 1: present. (This character is coded independently of character 8 because Pseudoplegmatograptus obesus possesses mid-ventral lists on the distal thecae, but not the first thecal pair).

10. zig-zag increments at distal part of thecal floor - 0: absent; 1: present. 
11. ancora sleeve- 0 : absent; 1 : present.

12. sicula length -0 : short, $<1.5 \mathrm{~mm} ; 1-$ long, $2 \mathrm{~mm}$ or more.

13. list ornamentation - 0 : finely striated/smooth; 1 : parallel ridges; 2 : pustules.

14. stomata - 0: absent; 1 : present (coded as "-" where there is no ancora sleeve).

15. ancora sleeve list density - 0: few lists; 1 : many lists (coded as "-" where there is no ancora sleeve).

16. apertural lip processes - 0: absent; 1 : present.

17. lateral aperture rod -0 : absent; 1 : present.

18. pleural lists -0 : absent; 1 : present.

19. tubarium shape - 0: widening rapidly; 1 : sub-parallel.

20. tubarium width - 0: wide; 1 : narrow ( $2 \mathrm{~mm}$ or less).

Documentation of the character states for each of the taxa described in this study are found in the descriptions, remarks and illustrations for each taxon. For those taxa not described in this study the sources of morphological information are as follows:

Pseudorthograptus obuti: Rickards and Koren' (1974): Štorch (1985); Koren' and Rickards (1996).

Pseudorthograptus inopinatus: Koren' and Rickards (1996); Melchin (1998); this study (Fig. 4); authors' unpublished data.

Hercograptus introversus: Melchin (1999).

Stomatograptus canadensis: Lenz and Melchin (1987a, specimens identified as Stomatograptus sp.); Bates and Kirk (1997, specimens identified as Stomatograptus sp.); Lenz and Thorsteinsson (1997, specimens identified as Stomatograptus sp.); Lenz and Kozłowska (2007).

Retiolites geinitzianus: Obut and Zaslavskaya (1976); Lenz and Melchin (1987b, identified as Retiolites); Kozłowska-Dawidziuk (1995).

Paraplectograptus eiseli: Lenz and Melchin (1987a); Lenz (1993); Kozłowska-Dawidziuk (1995); Lenz et al. (2012).
Sokolovograptus textor: Lenz and Melchin (1987a); Lenz (1993); Kozłowska-Dawidziuk (1995); Lenz et al. (2012).

\section{Appendix 3. Character state changes at nodes in cladogram}

The following is a listing of the numbered nodes and terminal taxa on the cladogram (Fig. 5.1) and the character state changes that occur at each node or taxon (e.g. $3^{1}=$ character 3 changes to state $1 ; \mathrm{h}=$ homoplasy; $\mathrm{r}=$ reversal; ? = uncertain).

Node 0: $9^{1}, 10^{1}, 16^{0}, 17^{1}, 18^{1}$ ?

Node 1: $3^{1}, 6^{1}, 12^{0}, 14^{1}$ ?, $18^{1}$ ?

Node 2: $5^{1}, 8^{2}, 14^{1}$ ?, $18^{1}$ ?

Node $3: 3^{2}, 19^{1}$ ?, $20^{1}$ ?

Node 4: $2^{1}, 5^{2}, 8^{3}, 10^{0} \mathrm{r}$

Node 5: $1^{2}, 19^{1} \mathrm{~h}$ ?, $20^{1} \mathrm{~h}$ ?

Node 6: $3^{1} \mathrm{r}, 4^{1} \mathrm{~h}, 9^{0} \mathrm{~h}$

Node $7: 7^{1}$ ?, $14^{0} \mathrm{~h}, 15^{0}, 19^{1} \mathrm{~h}$ ?, $20^{1} \mathrm{~h}$ ?

Node 8: $4^{1} \mathrm{~h}$ ?, $7^{1}$ ?, $8^{1}$

Node 9: $1^{1} \mathrm{~h}, 4^{2}$ ?, $11^{0} \mathrm{~h}$

Node 10: $4^{2}$ ?, $13^{1}, 17^{0} \mathrm{r}, 18^{0} \mathrm{r}$

Node 11: $9^{0} \mathrm{~h}$

Node $12: 1^{1} \mathrm{~h}$

Node 13: $4^{3}, 13^{2}$

Pseudoretiolites perlatus: $4^{1} \mathrm{~h}$

Pseudoretiolites hyrichus: $19^{1} \mathrm{~h}, 20^{1} \mathrm{~h}$

Pseudoplegmatograptus obesus: $16^{1} \mathrm{~h}$

Retiolites geinitzianus: $14^{0} \mathrm{r}$

Aeroretiolites cancellatus: $4^{1} \mathrm{~h}$ ?

Rotaretiolites cf. exutus: $16^{1} \mathrm{~h}$

Eorograptus spirifer: $11^{0} \mathrm{~h}$

Sokolovograptus textor: $6^{0} \mathrm{r}, 7^{2}, 12^{1} \mathrm{r}$

Accepted 23 March 2016 